
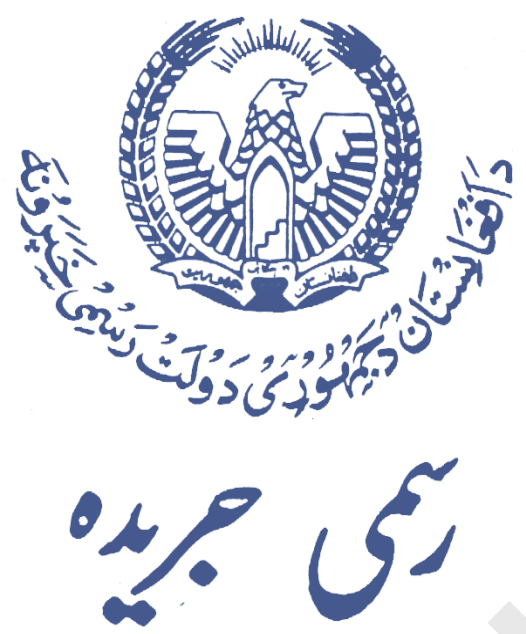

$$
\begin{aligned}
& \text { د-كهمو داصلاحاتوقانون } \\
& \text { قانون اصلاحات ا راضى }
\end{aligned}
$$$$
\text { لسمه كته }
$$$$
\text { يرله يسى نمبر (11) }
$$

نيته :حهار شنبه د ع عاب كالروزمرى دمياشتى (10) 


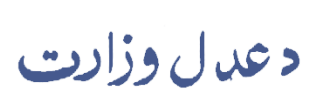

م.حسين(طغيان).

ع קمبب, مين)

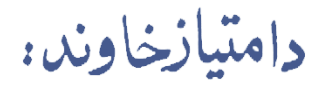

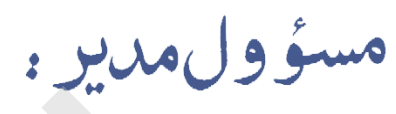

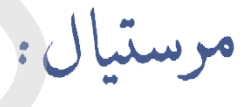

تّه : د عسل وزارت-كابل-افغانستان 


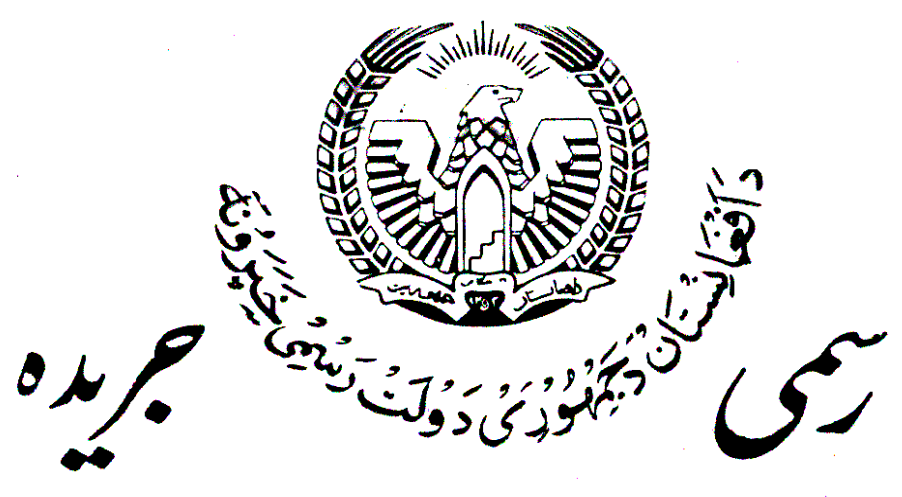

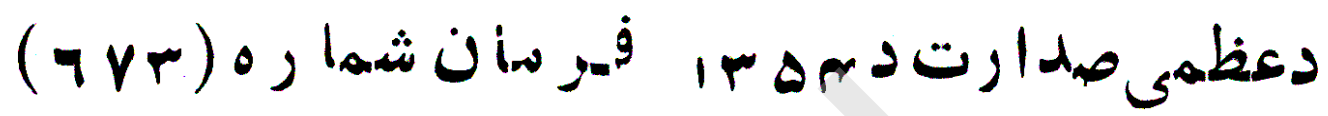

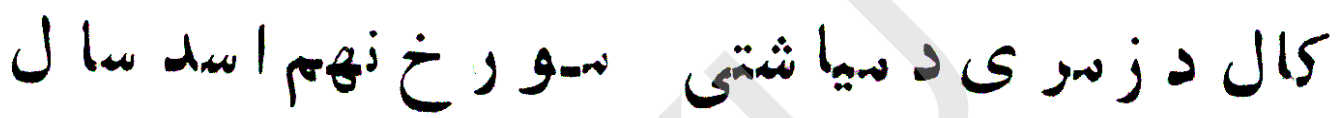

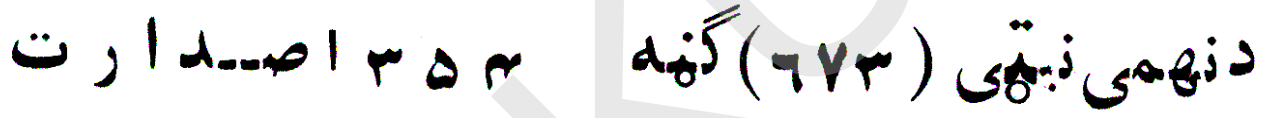
عظهى

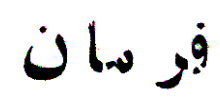

نباغلى دوكتور عبدا لمجيد وزير

:

مجلس وززواء تحت فيصلاشهماره

(1.09)

بناغلى دوكتور عبد المجيد عدليه

وزير :

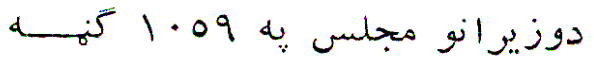

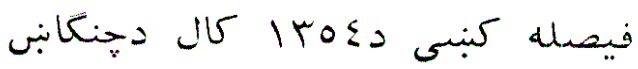

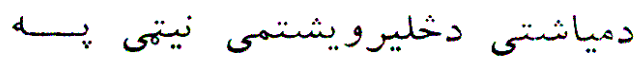

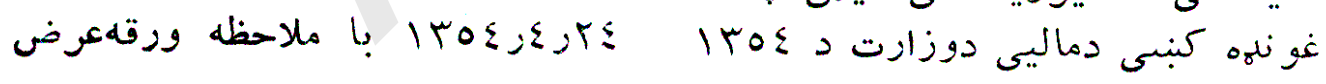
"

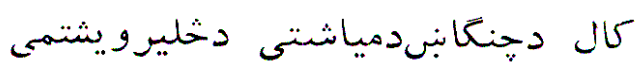

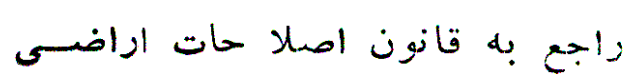

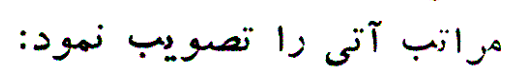

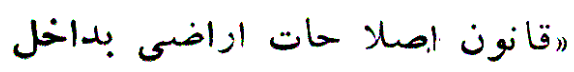

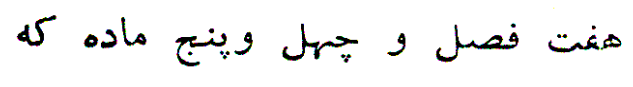
بهم دازالانشاء رسيده منظوراست.

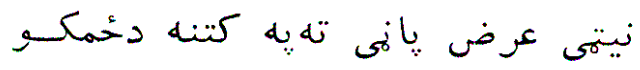

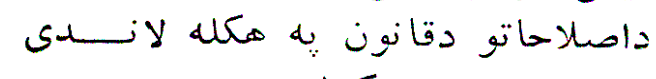

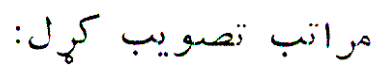

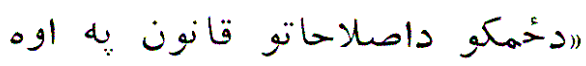

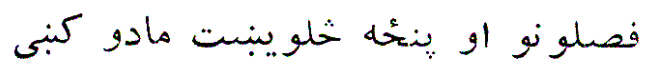

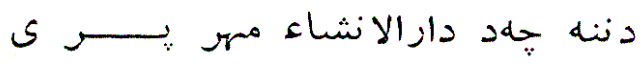

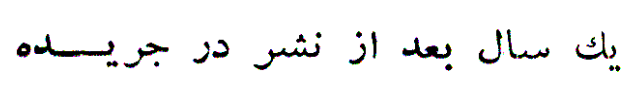
ردمهى نافذ هيباشد. وزارت ماليه

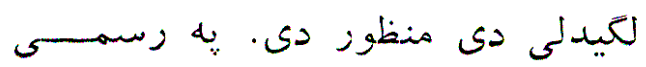

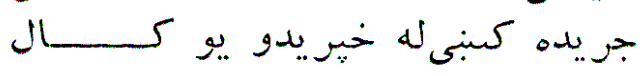

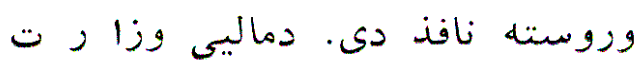

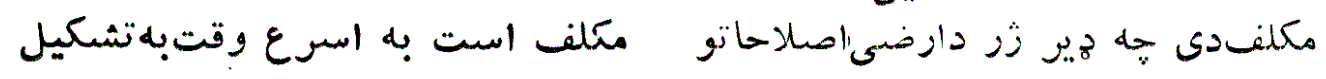




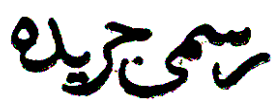

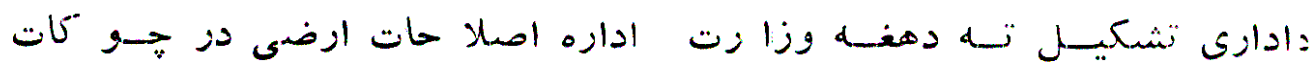

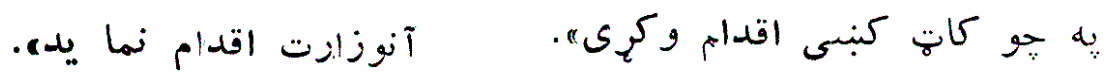

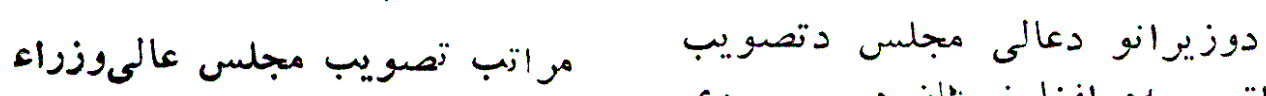

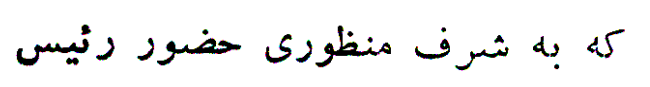

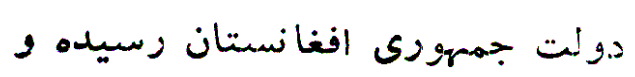
L

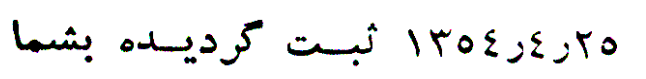

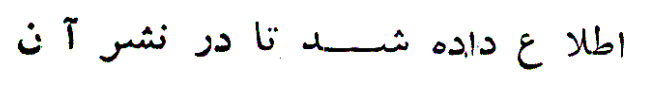
به جريده زسمى اقدام كردد. داكتر محمد حسن شرق

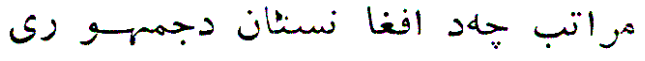

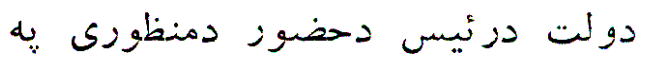

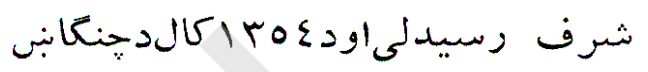

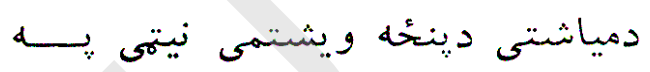

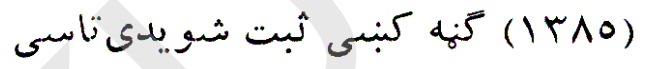

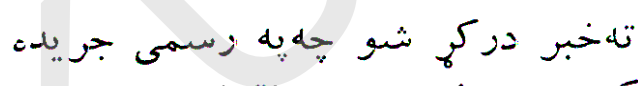

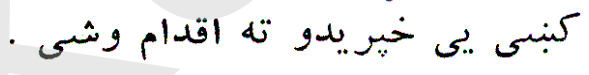
داكتر محمد حسن شرق 


\section{? P P}

الف - ز مين ملكيت دولت.

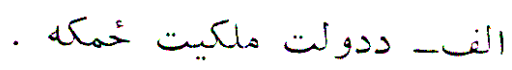

ب - زمين اضا فه جر يبى(مازاد)

اشنخاص.

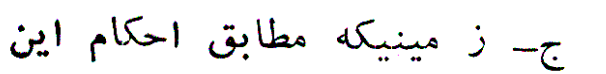
قازنون استملاك ميكردد.

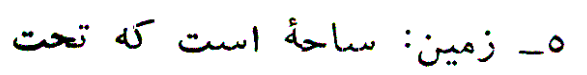

بهره بردارىزراعتى متداوله (مروجها قرال كيرد.

7- ساحة زمين دارى: يك ياجند

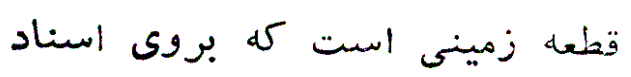
هعتبر قازونى ملكيت شخصشيت الثناخته

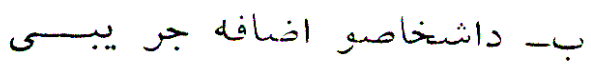

(مازاد)

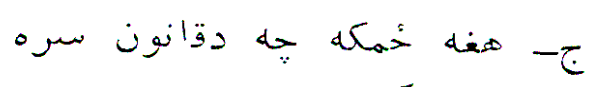
-

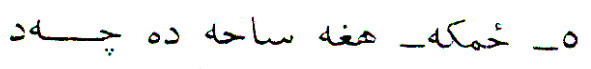

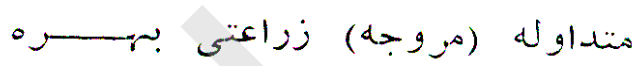

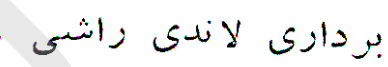

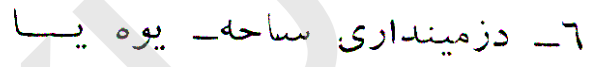

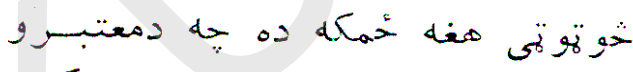

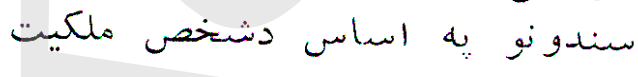
ش

V- دئيس خانوار: شخصى است

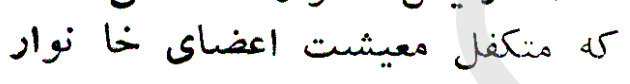
خود باشد.

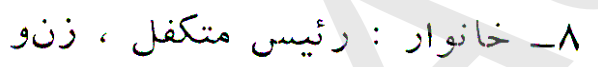

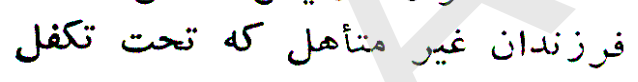

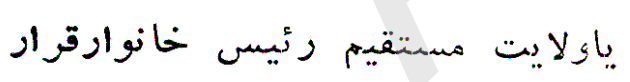

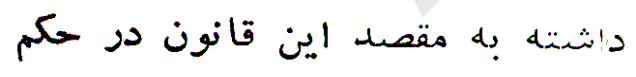
يك يك شتص شناخته ميشوند.

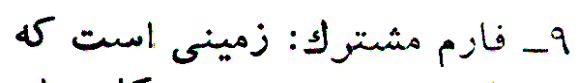

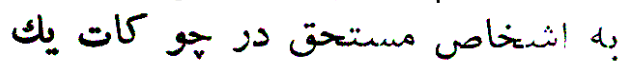

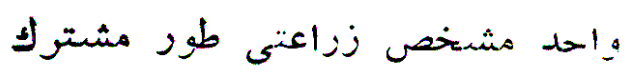
توزيع ميكردد.

• إـ شوزى: شورو إيعالى اصلاحات

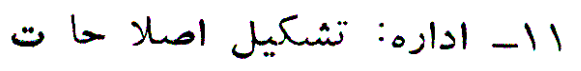

ارضى

ازضشى دز جو كات (وزاوت ماليه) .

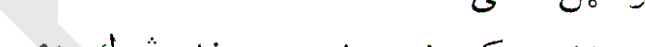

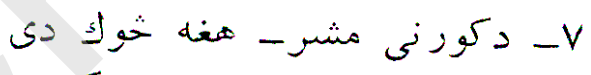

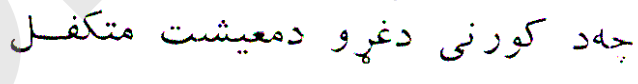
.

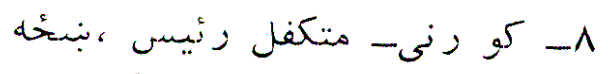

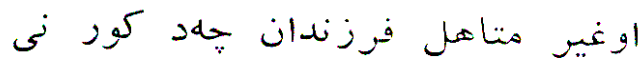

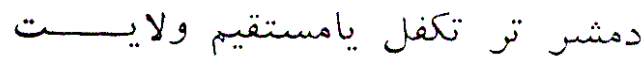

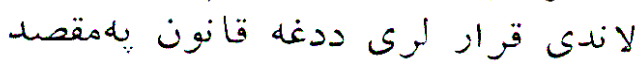

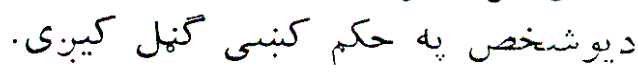

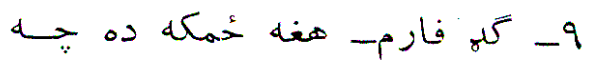

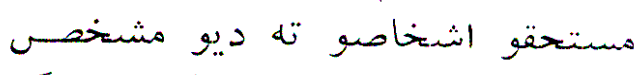

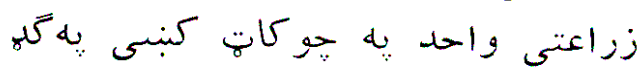

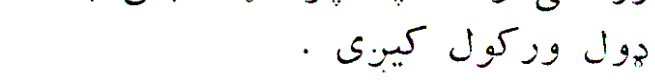

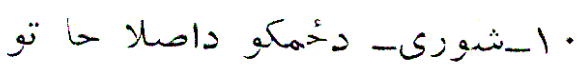
عالى شورى - لمثوري

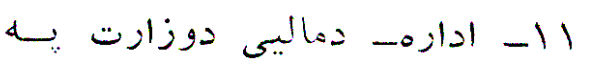

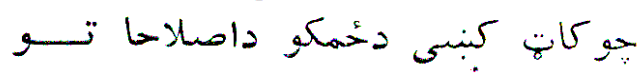
تصنيل 


\section{سئك}

\section{كار زراس كو بوبا تيف: كو يراتيسف

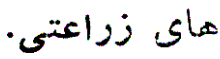 \\ فمل دوم}

حدود ملكيت زمين زراعتسى

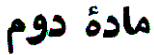

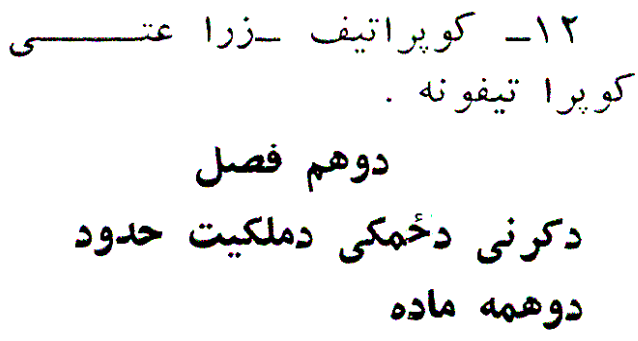

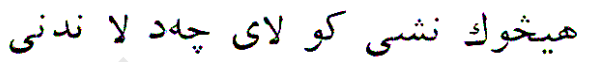

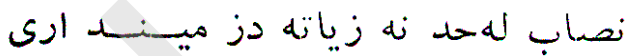

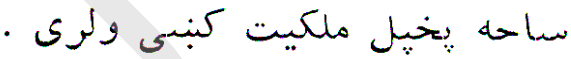
الف ـاوبه لرو نكى دوه فصلهـ دزميندارى ساحه سل جريبه يـلــاد

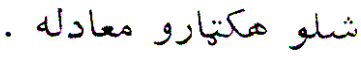

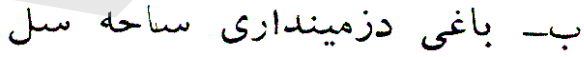

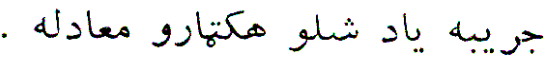
ج- اوبه لرو نكى يو فصله فيله دزميندارى معادله

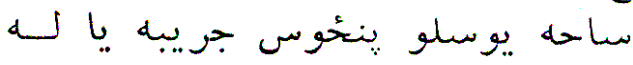

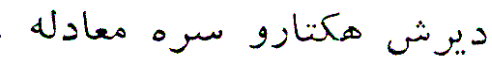

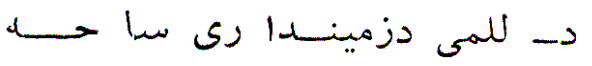

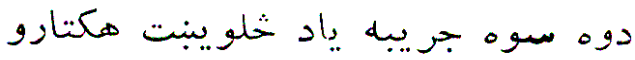

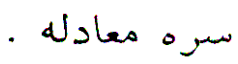
T- كن خيرى دشخص دفه دزميندارى

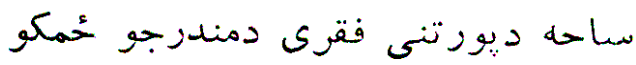

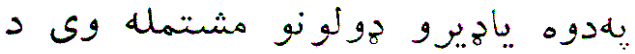

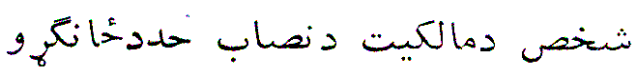

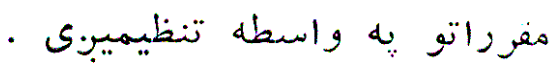
دريمه ماده

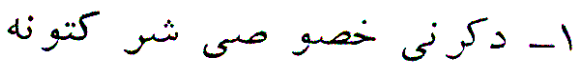

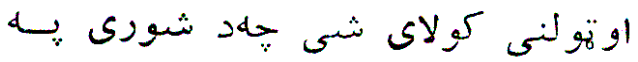

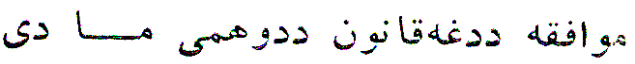




\section{? Pيدم}

ماده دوم اين قانون زمين در اختيار

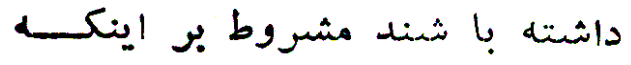
زمين اضافى باير بوده وآنرا قابل زوع سازند.

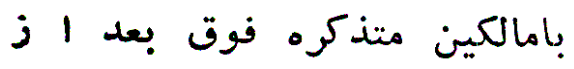

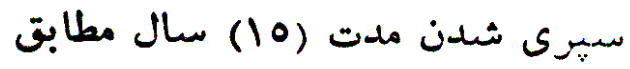

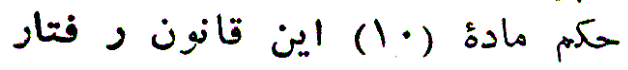
ميكردو.

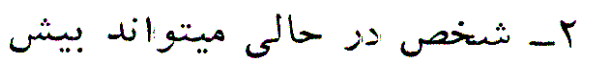

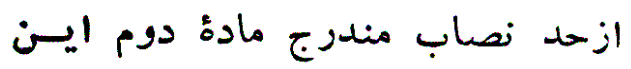

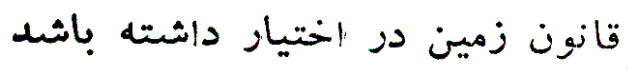

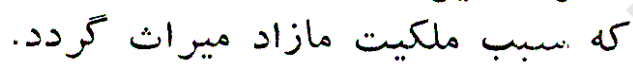

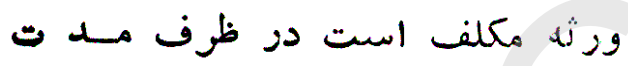

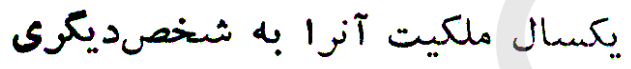

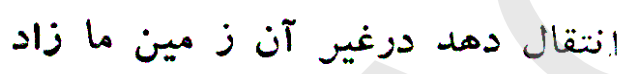
توسط دولت استمملاك ميكردد.

مادة حادم

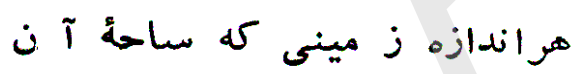
از نصاب مندرج ماده دوم اينقانون تجاوز كند بموجب الطلا عيه قبلى منلى ادؤ دون

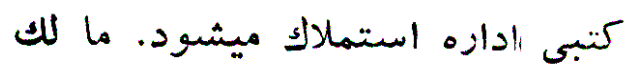

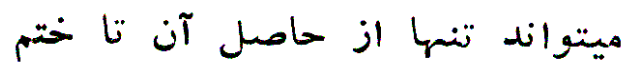
فصل ابستفاده كند.

مادة ينجم إنمادم

قيمت اشجار ، سده ختم ختمانسها و

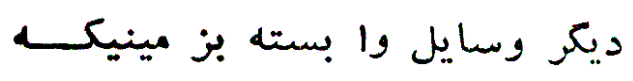
مطابق احكام اين قانون ، استـملاك

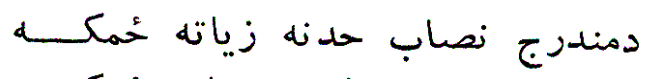

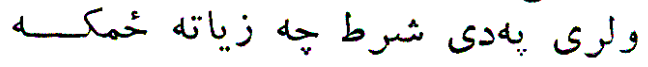

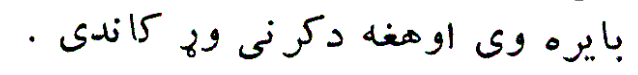

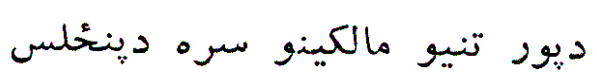

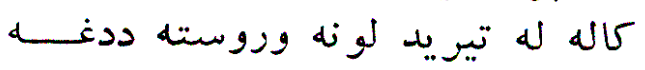

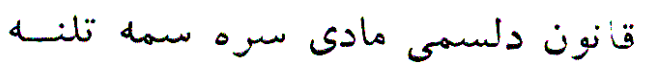
كب.ى

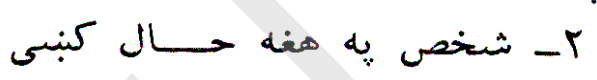

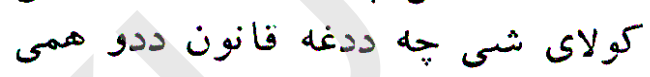

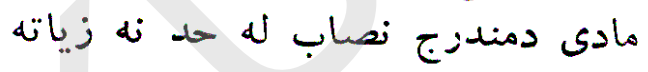

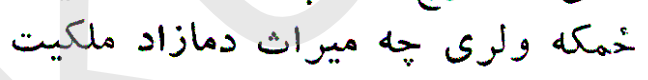

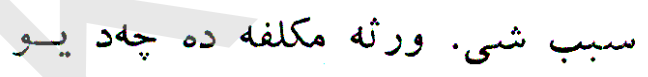

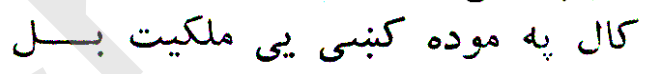

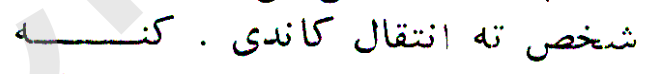

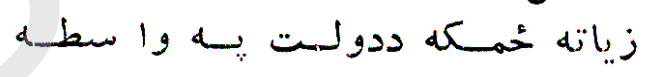
استملاكيب.ى. خلورمه ماده

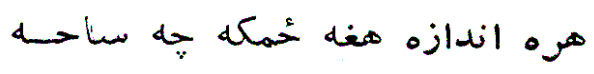

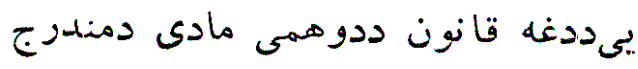

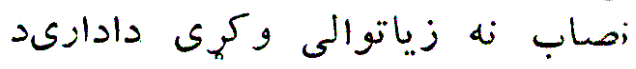

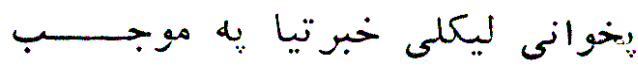

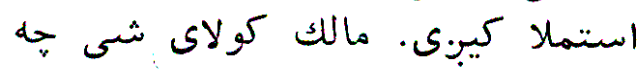

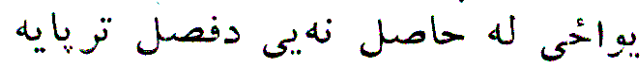

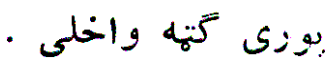

\section{ننحُمه ماده}

يهمغو خمكو קيورى دمو بوطو ونو، ماده

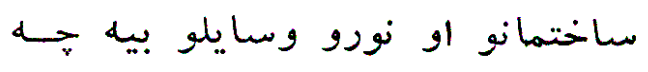
ددغه قانون دحكمونو سره سمون ونسيسى

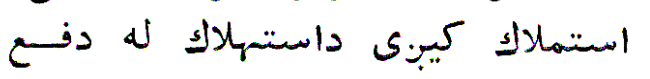




\section{थٓ}

ميكردد بعد از وضع استهلاكمطابق

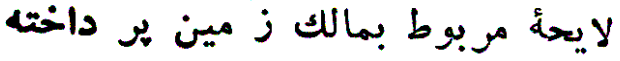
ميشسود.

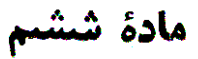

دولت بعد الز انفاذ اين قانــــون متو الياً به استملاك زمين هاى مازاد نصاب مندرج مادة دوم اين قانوبن ميير دازد. استملاك از منا طقيـكه

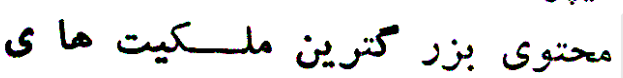
زراعتى است آغاز ميكردد.

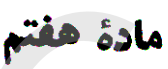

از تاريخ نفاذ اين قانون (اضانه

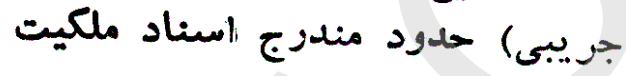
اشخاص ، ملكيت دو لت شئا ختود منسه

$$
\text { ميشود. مادة هثتم ، ماصر }
$$

دز صور تيكه تطبيت هيروزه هاى ازكشافى دولت إيجاب كند شوردى نطين

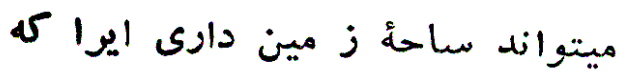

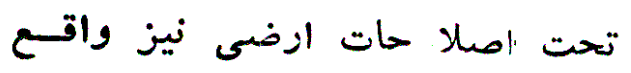
است با تعويض زمين ديكويكهداراي اصي

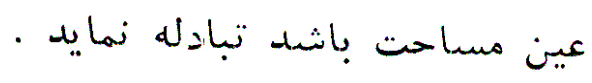
مادة نهر مين

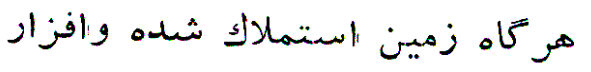
وابسته به آن تحت تضمين قر ار اردن

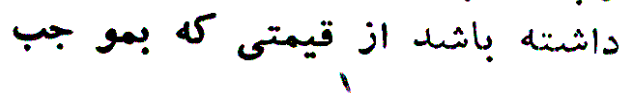

كولو نه وروسته دمربوطى لايحسـى تهو

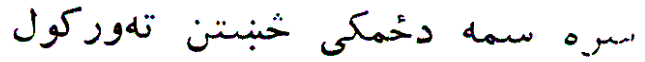

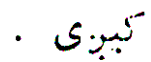

شير.مه ماده

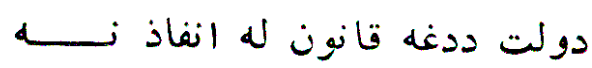

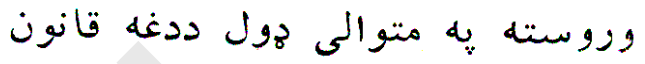

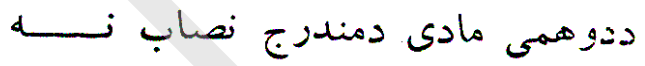

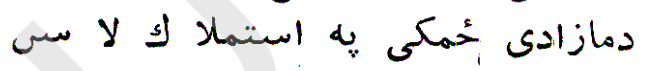

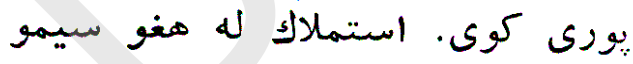

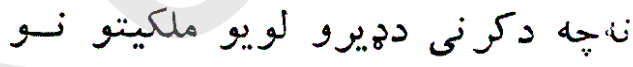

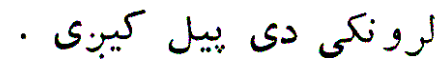
اومه ماده لرى

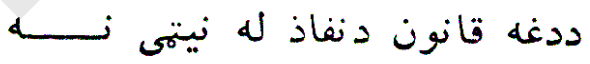

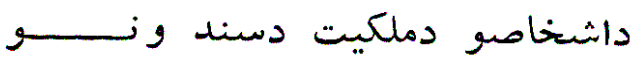

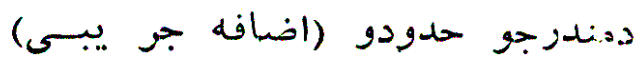

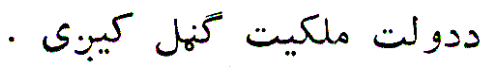
اتمه ماده

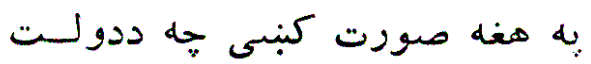

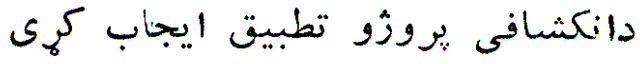

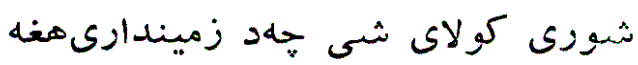

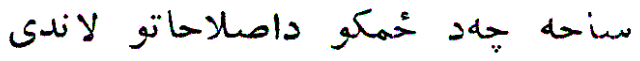

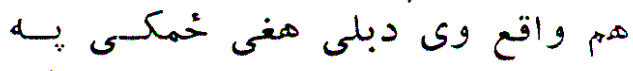

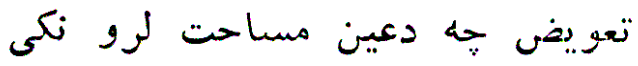
وق تبادله كاندى دئ دين

\section{نهمه ماده نبادله}

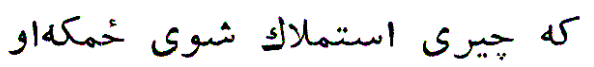

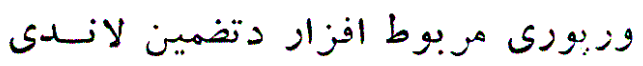

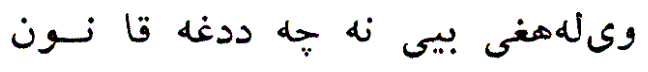




\section{थुद्र}

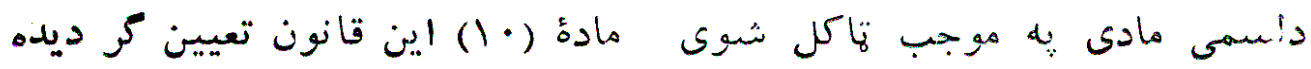

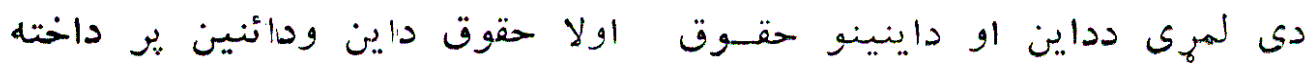

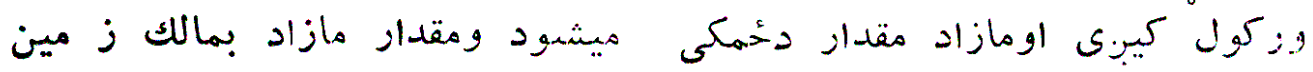

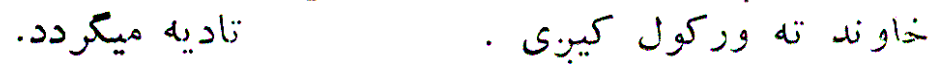

\section{مادة دهم} لسمه ماده

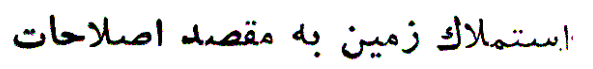

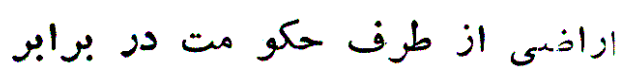
تعويض صورت ميكيرد. قيمت زمئ دمين

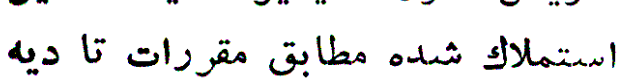
قيمت، تنظيم ميكردد.

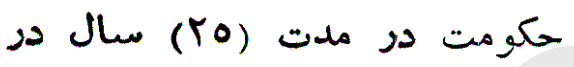

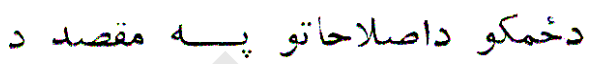

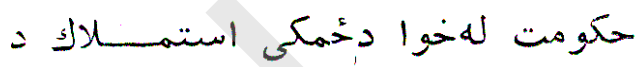

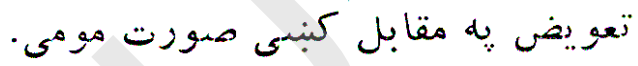

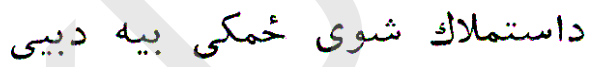

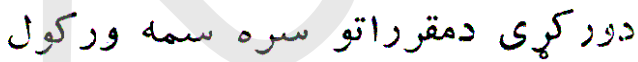

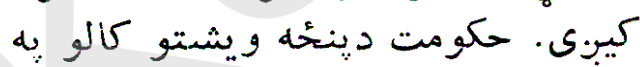

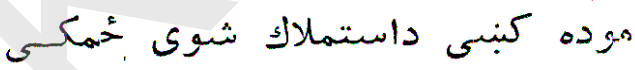

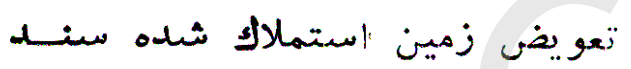

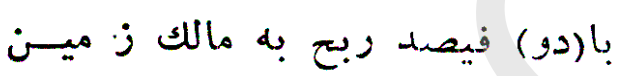
هيب دازد. في

\section{كومل سوم \\ توزيع ز مين}

\section{هادة يازدهم}

زمين هائيكه مطابق احكام ايسـن

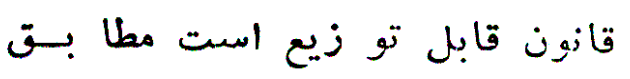

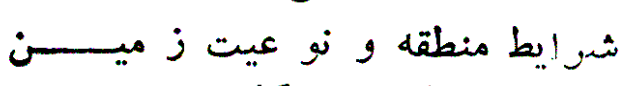

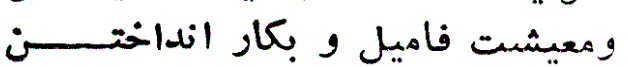
اعضاى آن و ساير معيار هابهاساس ونس وناس مقررات جدا كانه تو زيع ميكردد..

\section{مادة دوازدهم}

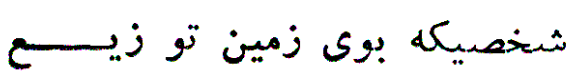
ميكردد بايد و.اجد شرايط ذيلباشد:

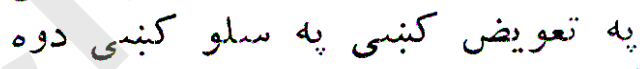

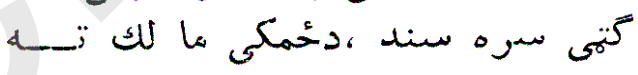
وزكوى .

\section{دريم فصل}

\section{ونخمكى ويش فمب}

\section{يولسمه ماده}

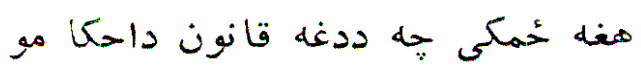

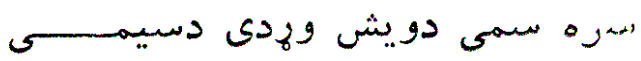

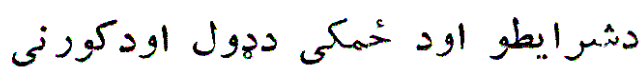

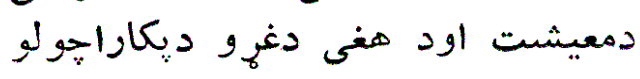

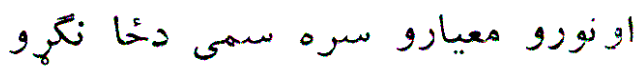

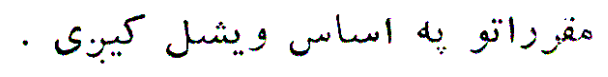

\section{دولسمه ماده}

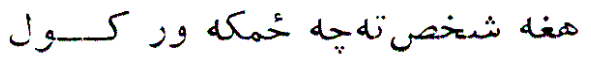

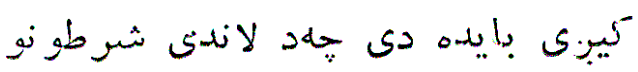
نرون نكى وى : 


\section{م אבינת}

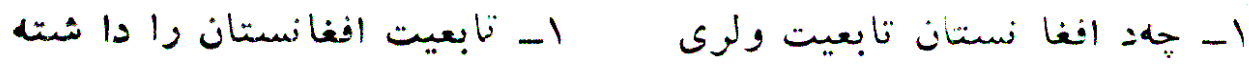

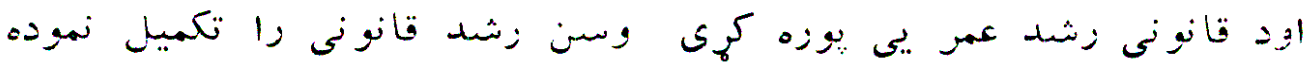

$$
\begin{aligned}
& \text { باشد. } \\
& \text { r- بـ زمين باشد. } \\
& \text { ماده سيز دهم زمي } \\
& \text { وى } \\
& \text { ديار لسمه ماده }
\end{aligned}
$$

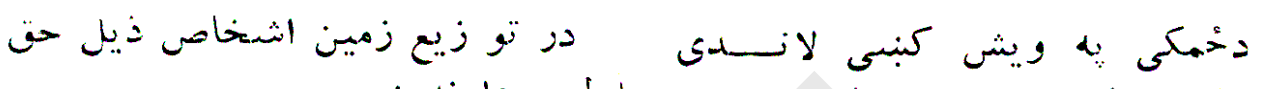

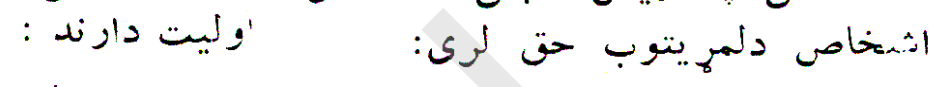

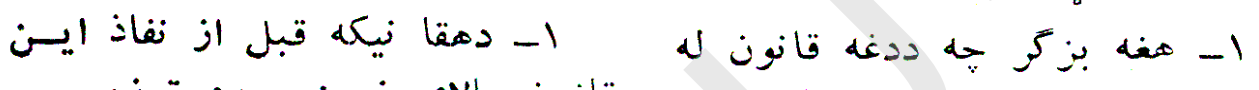

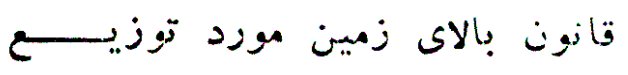
هصروف كار زراءتى باشد.

r

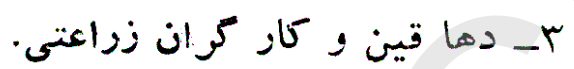

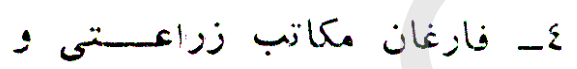

.

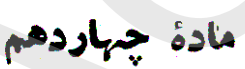

توزيع ز مين مطابق يلان مو تبه

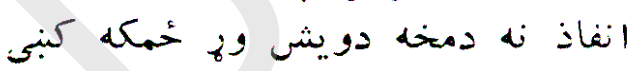

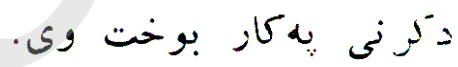

r

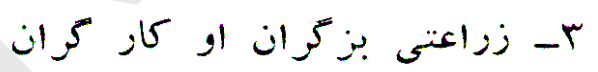

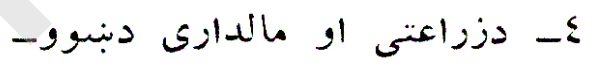

زخئيو فارغان

\section{خوار لسمه ماده}

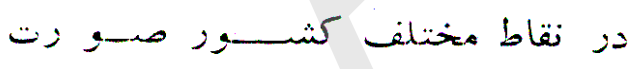

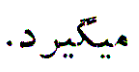

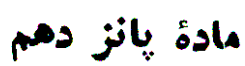

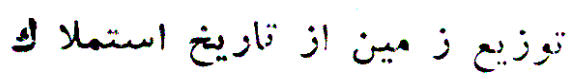

$$
\text { بدون و فقه صوزت مئ ميكيرد. }
$$

\section{مادة شانزدمى ونه}

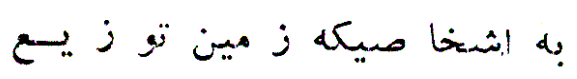

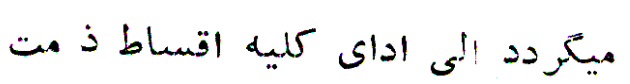

وى، 'زطرفدولتسند ملكيت مؤقت

$$
\text { دايه هيشبود. }
$$

دئمكى ويش دتوتيب شبوى بيلان

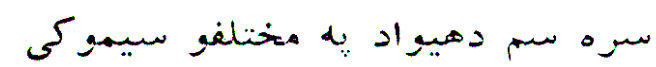

صورت مومى سمئ

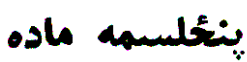

دخدمكى ويش داستملالك له له نيتهى ماده

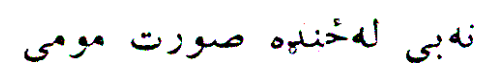

$$
\begin{aligned}
& \text { شياجسمه ماده }
\end{aligned}
$$

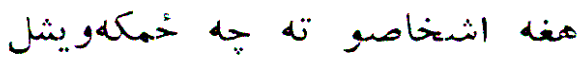

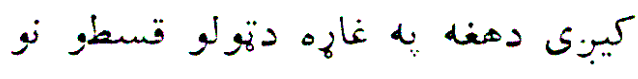

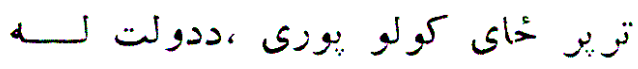

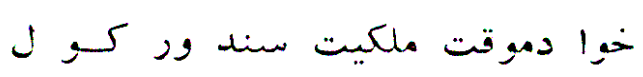

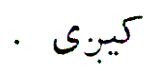




\section{Q}

\section{مادة هفدهم}

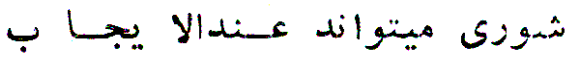

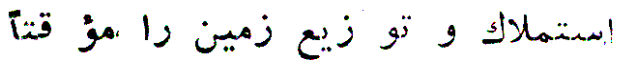
هتز قنف سازد.

\section{هاده هجدهم}

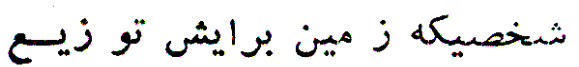
هيكردد به انجام وجايب ذيل ذيل مكلف

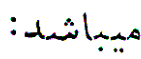

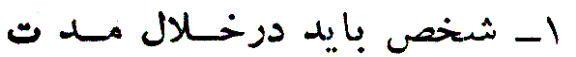

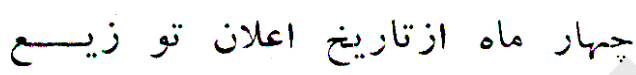

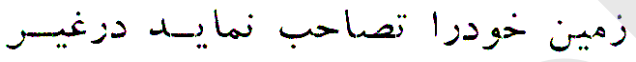

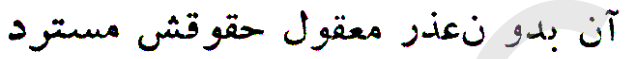

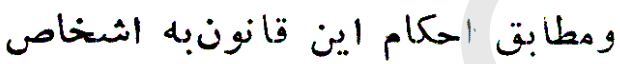
ديكّر و!جد شرايط تو زيع ميكردد.

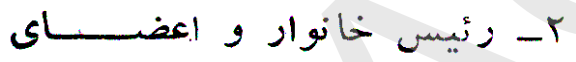

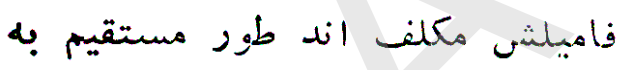

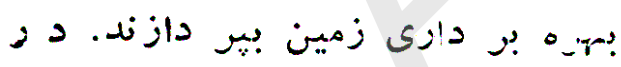

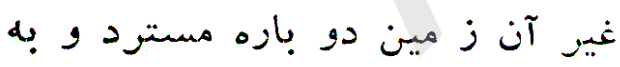

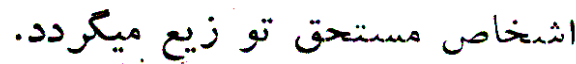

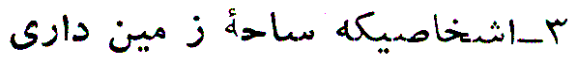

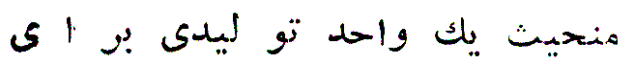

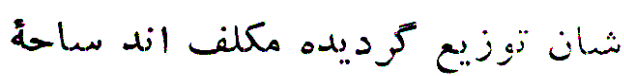

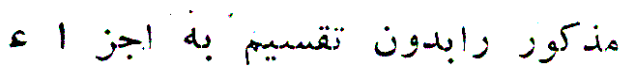
حغظ زمايند.

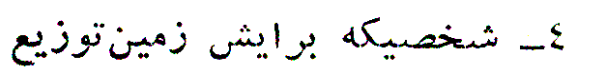

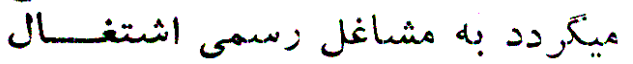

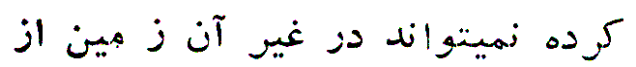

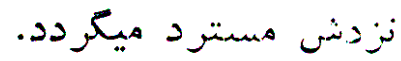

\section{اولسمه ماده}

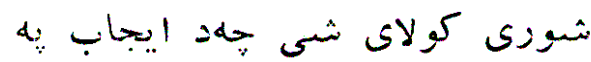

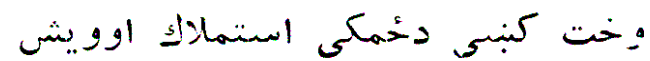

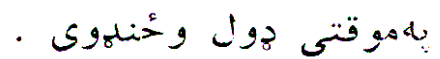

\section{إتلسمه ماده}

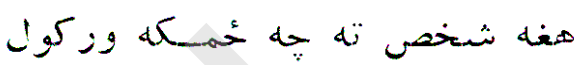

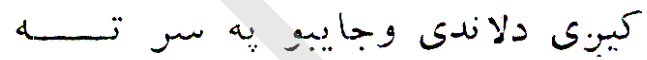

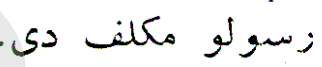

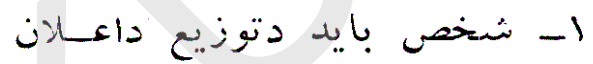

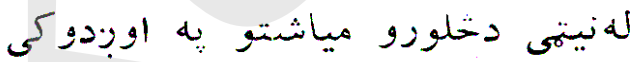

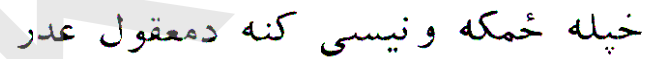

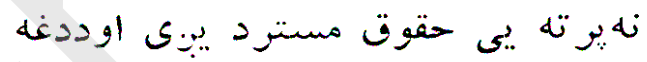

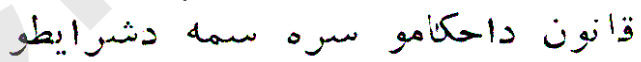

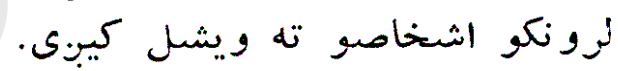

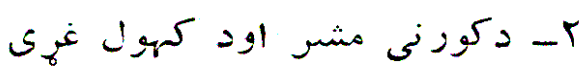

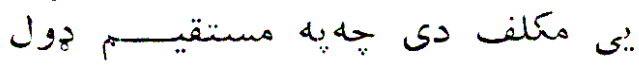

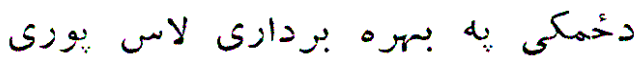

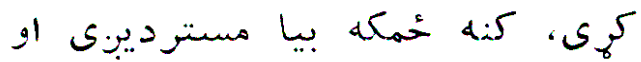

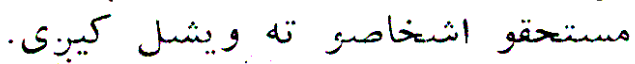

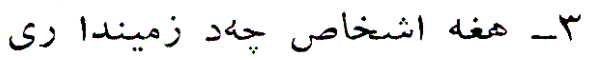

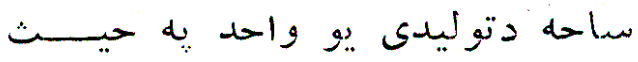

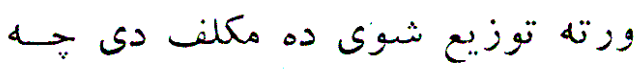

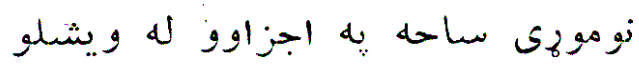

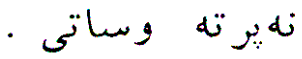

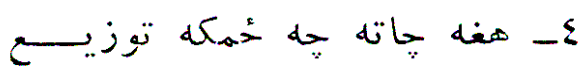

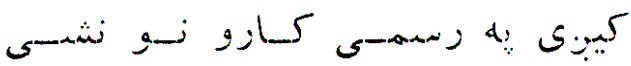

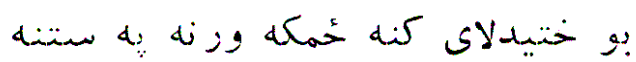
• اخشستل كيبن 


\section{P.}

\section{مادة نزدهم}

نولسهه ماده

1- هر كاه رئيس خانوار فو ت تورئ

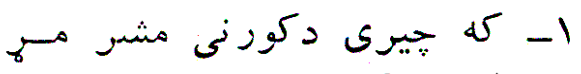

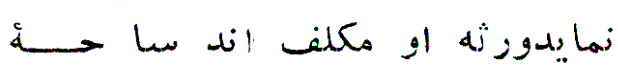

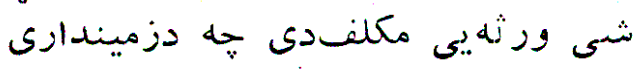

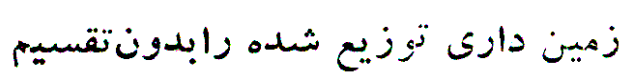

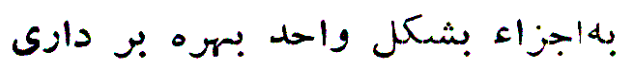

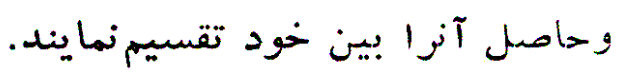

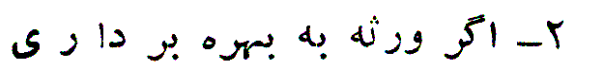

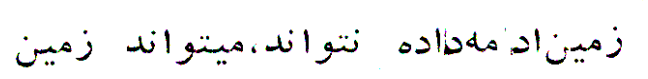

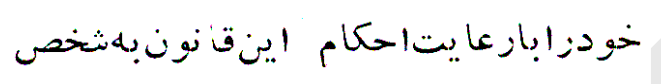

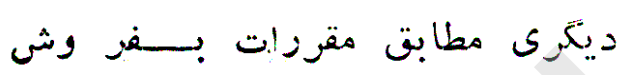

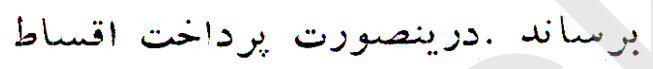

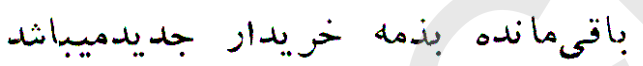

\section{مادة بيستم}

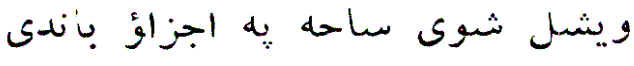

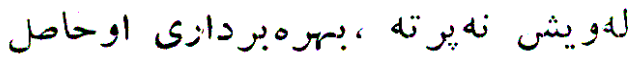

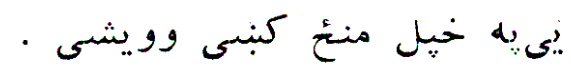

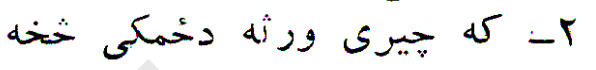

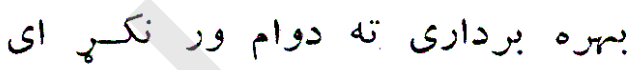

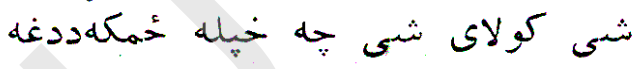

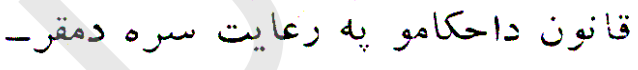

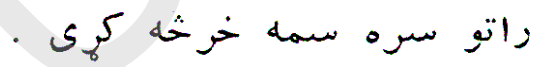

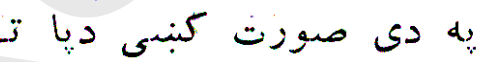
قنسطونو وركيهة دنوى بيرو دون دو نكى نسى

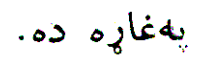
شلمه ماده

هر كاه رئيس خانوار فوت نمايد

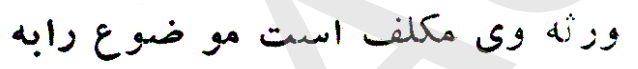

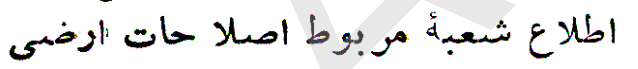

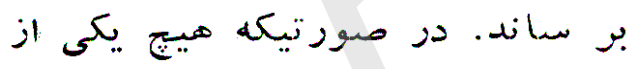
وزثه اهليت معا ملا تى نداشتهبه دياشد إدازه مكلف است براى دوله دوام بهره

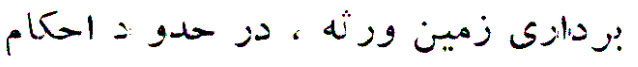
قوازين و مقررات مو ضمو عهله تدا بيي لازها اتخاذ كند.

\section{مادة بيست و يكم}

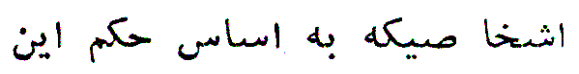

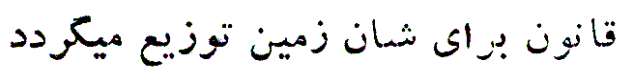

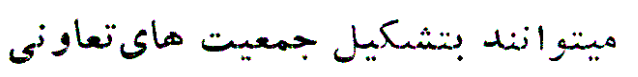
بيي دازند.

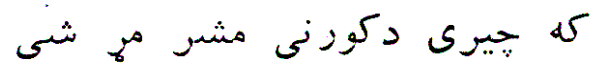

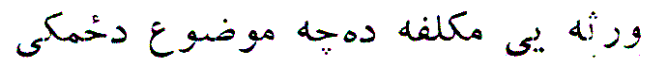

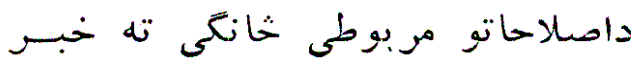

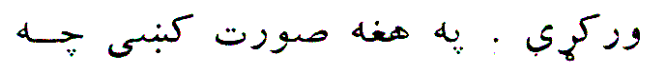

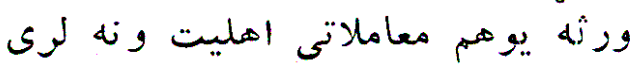

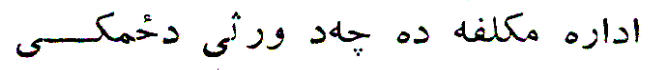

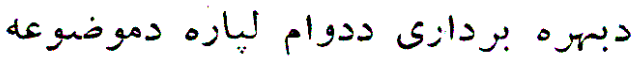

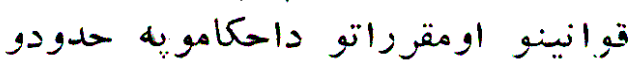

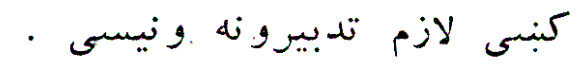

\section{يوويشتمه ماده}

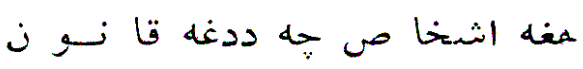

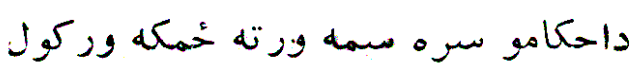

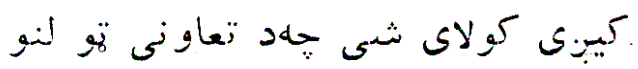

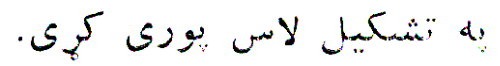




\section{था}

\section{مادؤ بيست ودوم}

مالك زمهن كه مطابق احكام اين

قانون برايش زمين توزيع كر ديده

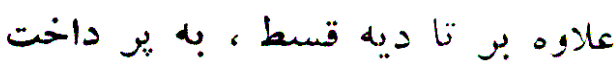

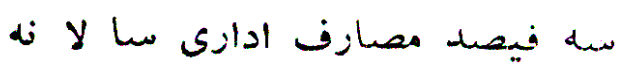

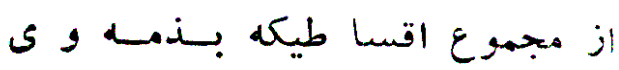

$$
\begin{aligned}
& \text { باقيست نيز مكلف ميباشد. } \\
& \text { فمل حهبادم } \\
& \text { تشكيلا ت }
\end{aligned}
$$

\section{ماده بيست وسوم}

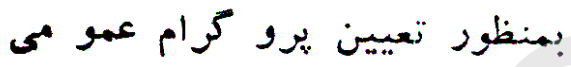

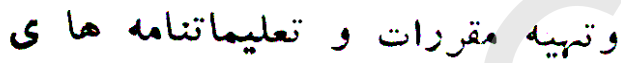

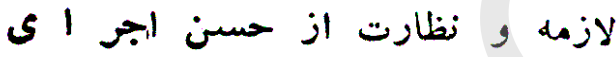

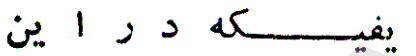

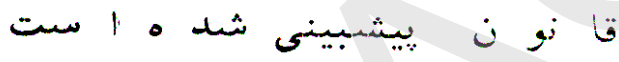
وبمنظور عملي نمودن اهدافريفوري

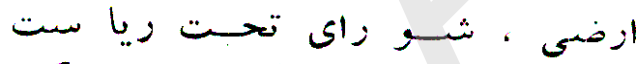

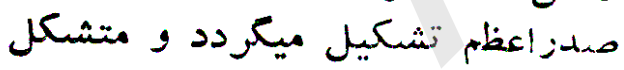
از اعضداى ذيل ميباشد:

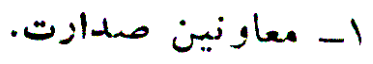$$
\text { r- وزيو عدليه. }
$$$$
\text { ب- وزير ماليه. }
$$$$
\text { ؟- وزير هيلان. }
$$$$
\text { هـ وزير زواعت. }
$$

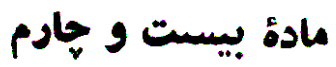

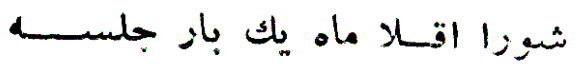

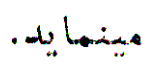

دوه ويشتمه ماده

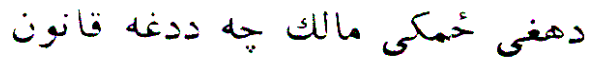

داحكامو سره سمه ورته

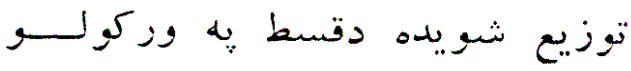

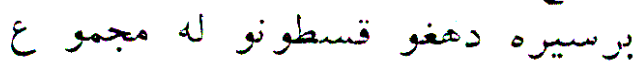

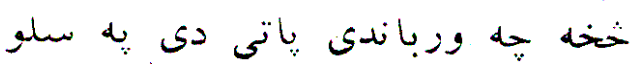

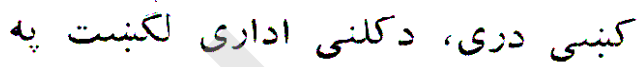

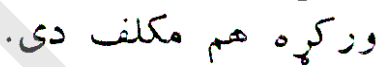

خلورم فصل تشعيلات

در ويشتمه ماده

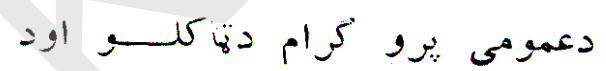

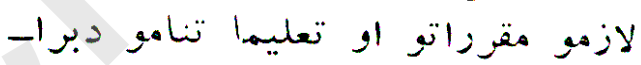

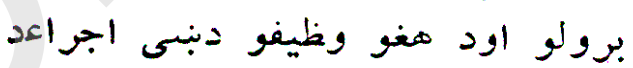

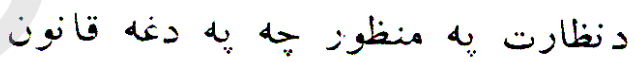

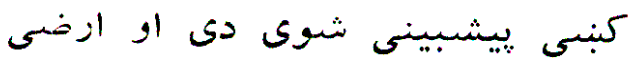

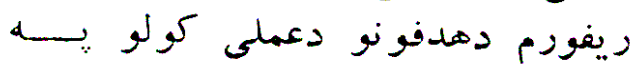

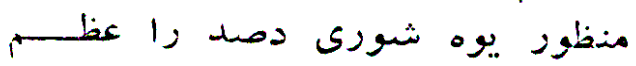

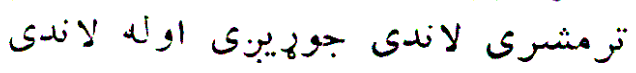

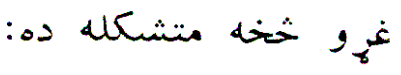
1- دصدارت مرستيا لان

$$
\begin{aligned}
& \text { r } \\
& \text { r- دماليى وزيو }
\end{aligned}
$$

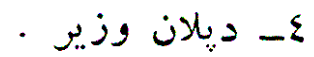

$$
\begin{aligned}
& \text { هـ دك نى وزير . }
\end{aligned}
$$
خلير ويشتمه ماده

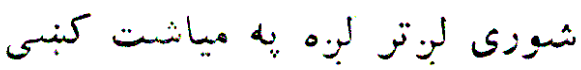

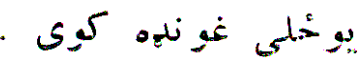




\section{थु)}

\section{مادة بيست ورينجم}

صلا حيت هاي شوزا يعا لى فوراز ذيل است:

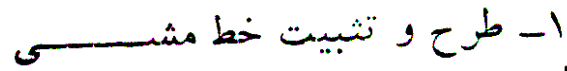

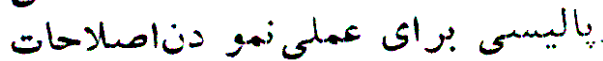

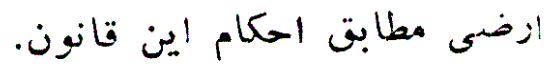

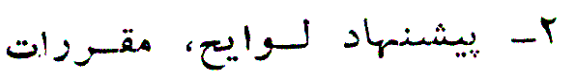

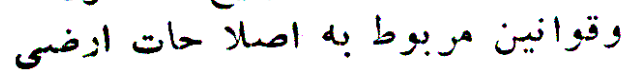

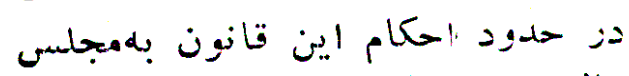
عالى وززاء.

r- نصويب وتعيين قيمت ورزع اراضى

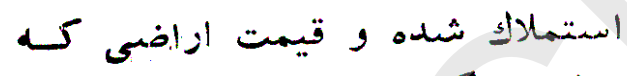
توزيع ميكردد.

عـ اتخاذ تصا ميم در بارةٔمسايل

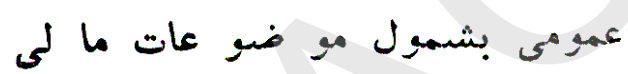
ادازه.

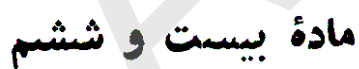

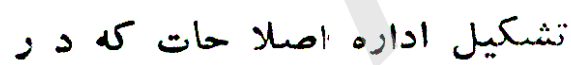

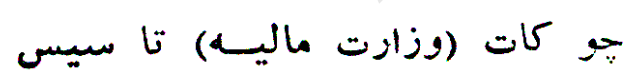

ميكر دد به بيشنههاد شورى وتصويب

مجلس عالى وززاء صورت ميكيرد.

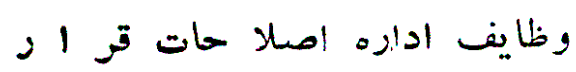

$$
\text { آنى است: }
$$

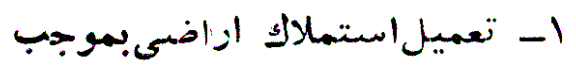

$$
\text { احكام اين قانون. }
$$

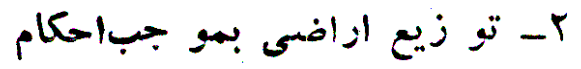

$$
\text { إين قانون. }
$$

\section{ينتحه ويشتمه ماده}

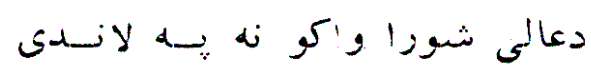
نول دى:

1- ددغه قانون دان داحكامو سرهسم

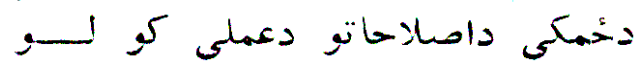

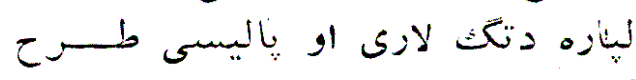
كول .

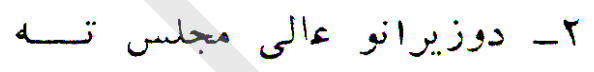

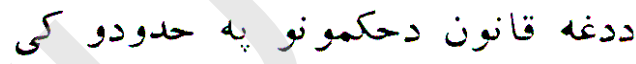

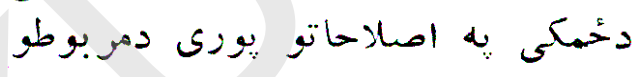
لايحو، مقرزاتو او قوانينو بيشنهاد.

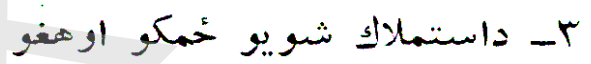

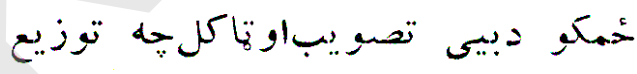
كيب.ى

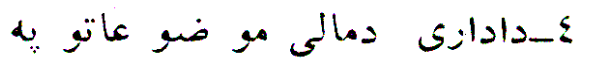

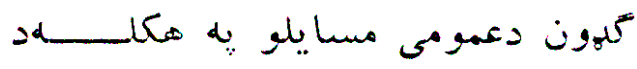
تصميمونو نيون دعمون مئر شيبز ويشتمهه ماده نيول داصلا حاتو دادارى تشكيل جئه

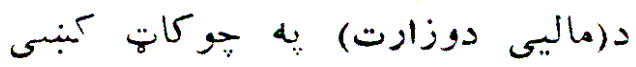

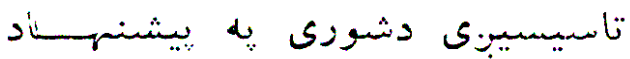

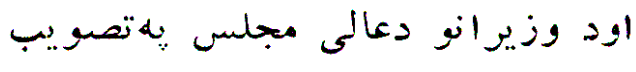

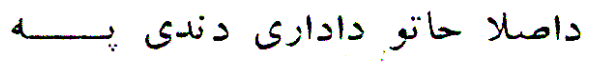
لاندى هول دى:

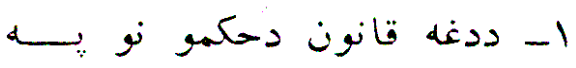

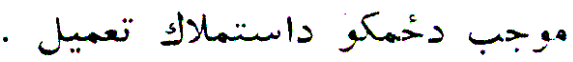

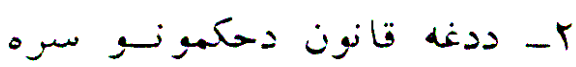

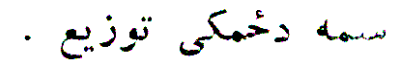




\section{تيمتحين}

r- ار تباط با مقا مات ذيعلا قه إنه

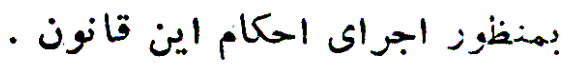

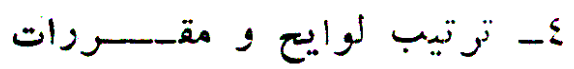

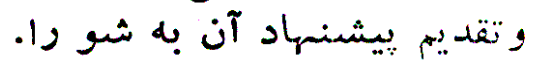

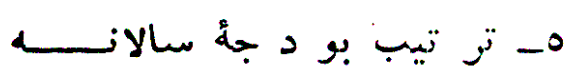
ومنظوزى آن از مقا مات صلا حيتداز طبق قانون بودجه و محا سبه.

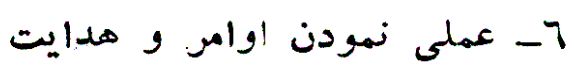
شوزا.

V- تعيين قيمت تأسيسات آلات

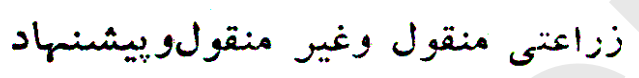
آن به شوزاء 1- معلوم زمودن حالاتاستثنانقى و بينشنهادآن به شورا.

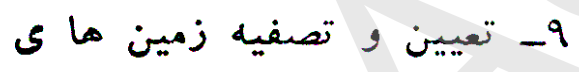

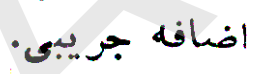

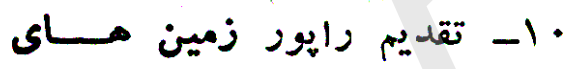

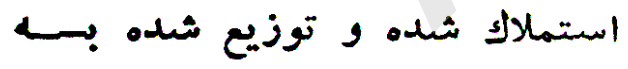
شوزا. 11 - ساير اختيا رات وصلا حيت

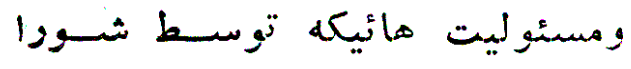
تعيين ميشود

\section{ماده بيست وهفت ميشت}

بمنظور رفع اختلا فات كه نا شى بدى

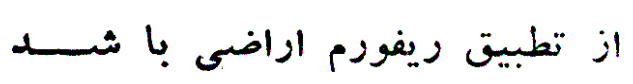

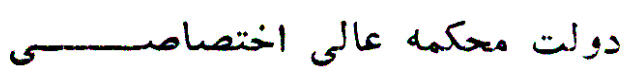

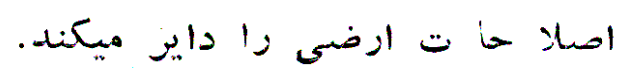

r- دعلاقه لرونكو مقاماتـو سوه

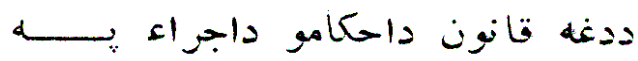
منغئور ارتباط قانون داحن

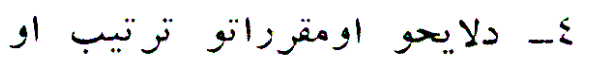

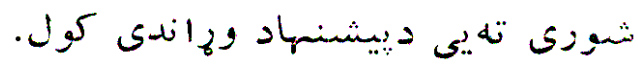

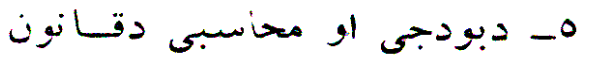

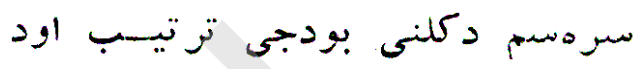

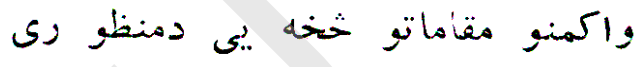

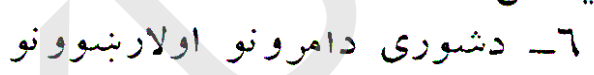

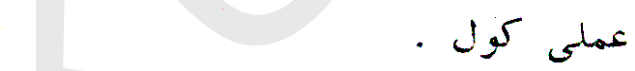

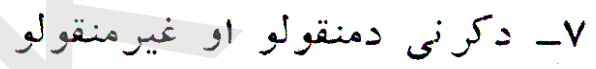

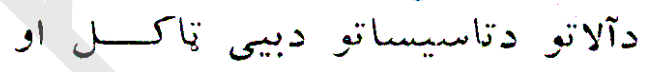

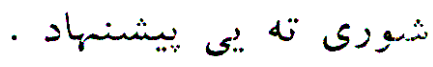

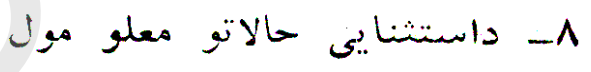

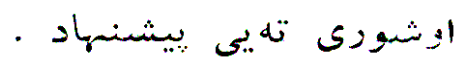

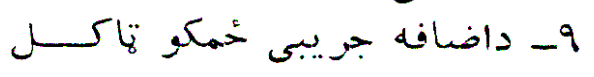
او تصغيه .

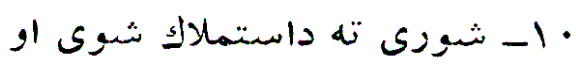

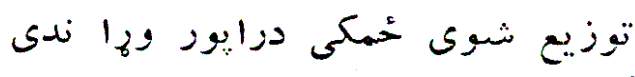
ك او الـ- نوز هغه اختيازات ،واكونه

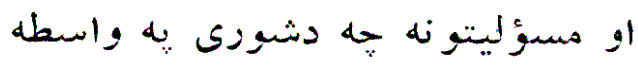

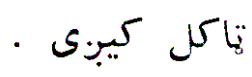
اوه ويشتمه ماده دهغو اختلا فاتو دلرى كولي لهاره

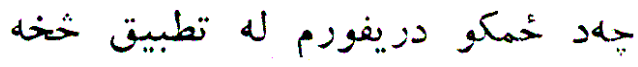

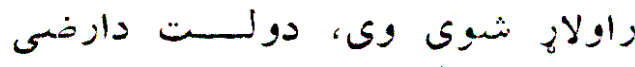

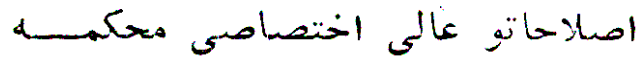
. 


\section{Sons?}

\section{مادهٔ بيست و مشتم}

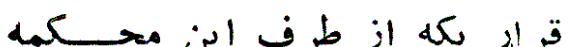

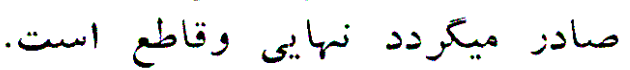

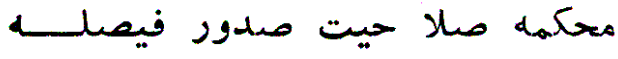
و نقض وابرام رانيز دارد.

\section{ماده بيست ونهم ونه ونه}

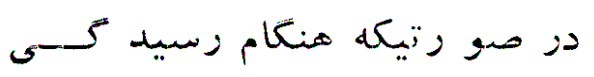

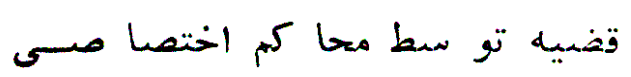

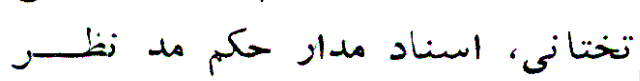

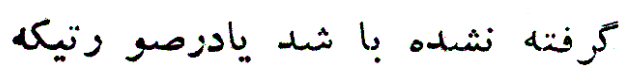

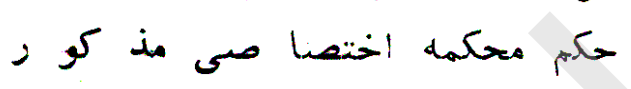

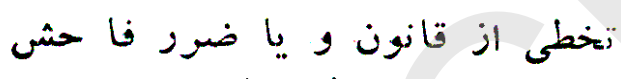

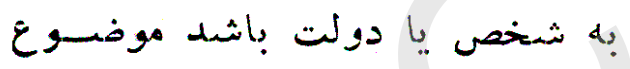

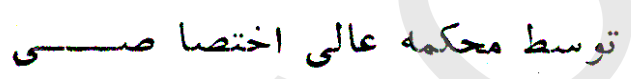

$$
\text { زميدكى ميكردد. }
$$

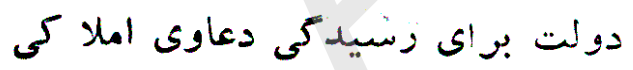

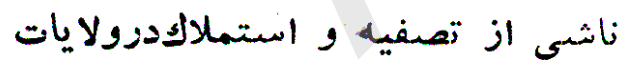

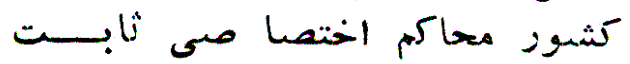
ياسيار داير ميكند.

\section{ماده سى ويكم}

محكمله هاى اختصا صل صى ديم دزموزد

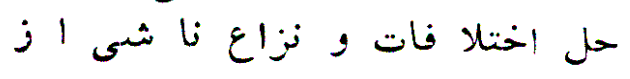

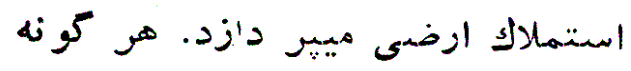

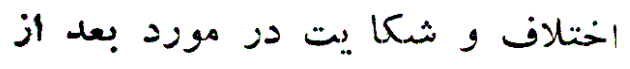

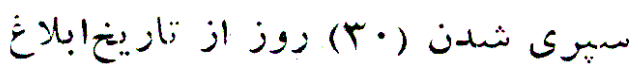

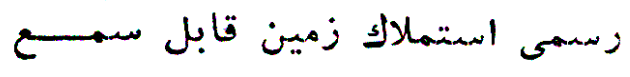

\section{انه ويشتمهه ماده}

هغه قراز جه تدغغى محكمى له وخوا

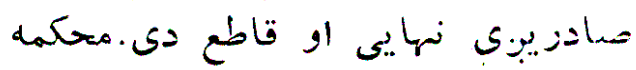

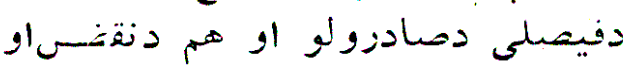

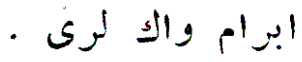
نه ويشتمه ماده

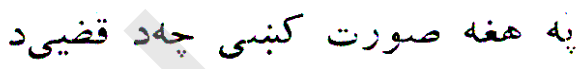
غوز ،يه وخت كنبس دنه دتحتانى اختصاصى

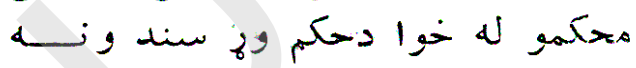

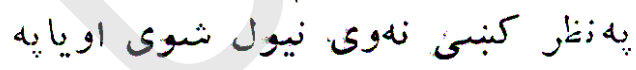

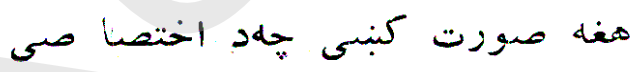

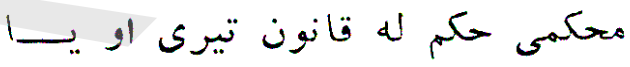

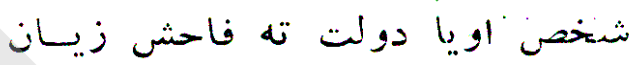

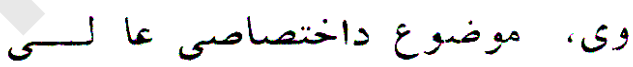

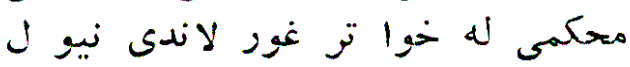

\section{ديرشمه ماده}

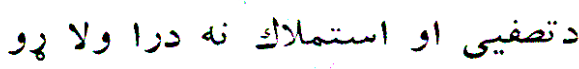

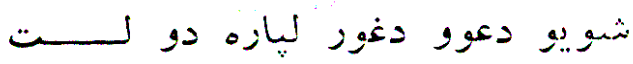

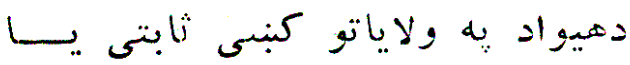

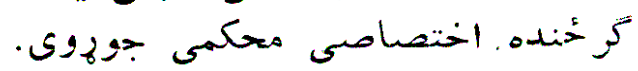
يو ديرشمه ماده

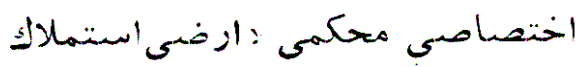

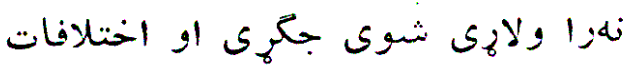
حل كوى نه نول

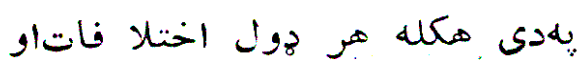

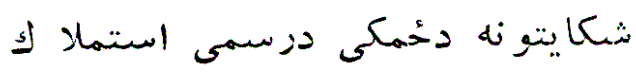

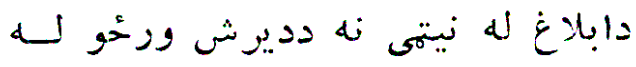

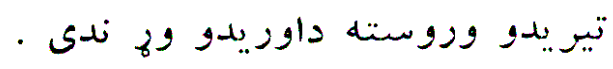




\section{كّ}

مادة سى و دوم

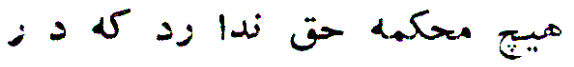

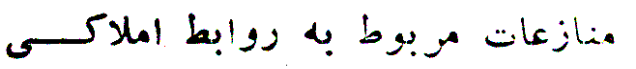

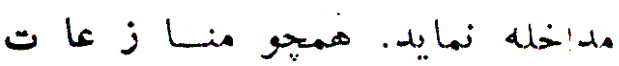

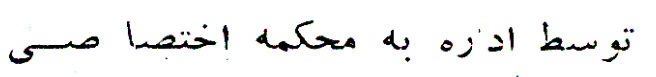

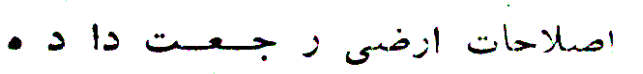

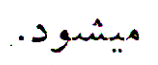

قصسل يثبم

كويراتيف هاى زراعتى

هادة سى وسوم
دو ديرشمه ماده

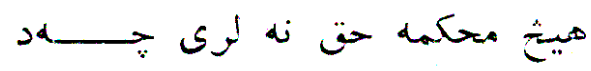

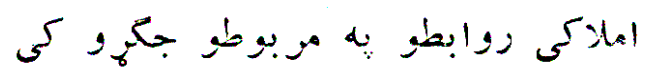

لانس ووهى.

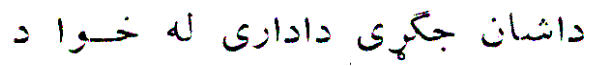

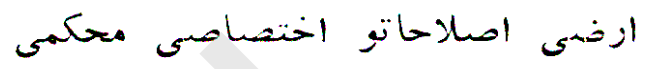

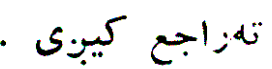

نينمئم فصل

زراعتى كويرا تيفونه

درى ديوشمه ماده.

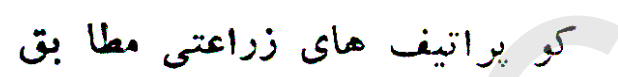

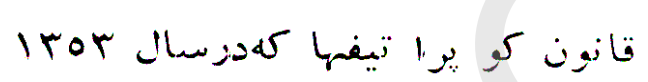

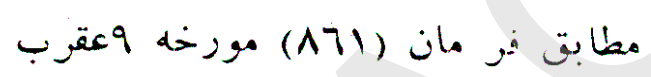

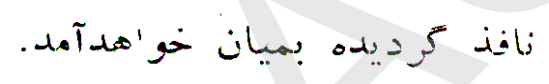

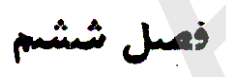

امود مالـى تصني

مادهُ سى و جارم

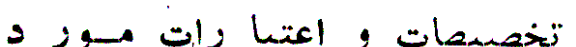

خسزوزت براى اجراى اين قا نو ن وعبالغ هربوط به اداره واجرا آتيكه دززهينه اصلا حات ارضى بعمى بردسل

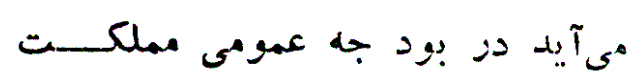

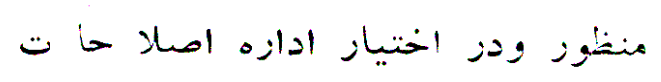
ازثشى قراز داده هيشمود.

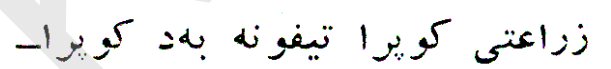

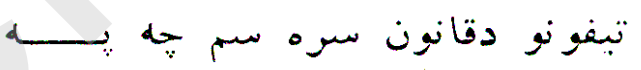
هنr

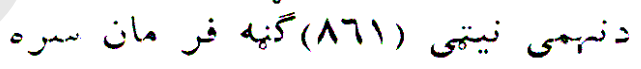

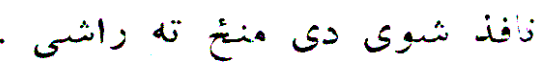

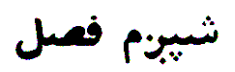

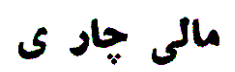
خلور ديرشهه ماده

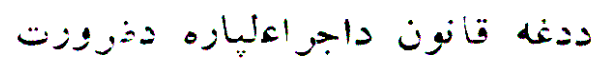

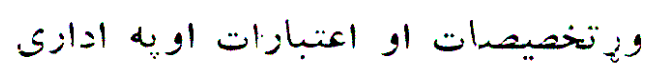

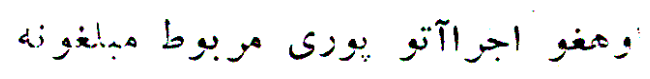

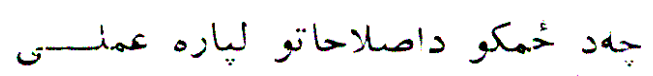

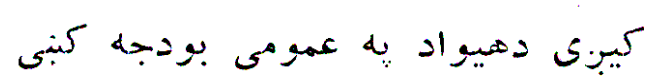

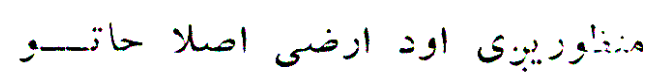

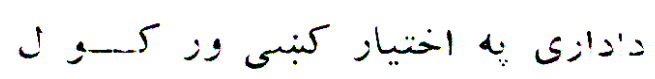




\section{(50\%}

مادة سى وينجم

اسناد قباله ماى زمين ماد ونوزيع شله بطور امانت به بانك زرا عتى افغانستان تحويل داده ميشودوبانك مذكور به وكالت دولت مكلف است

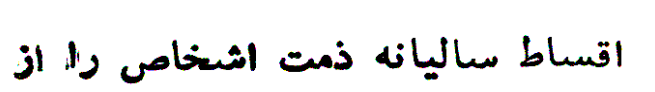
درك قيمت زمين حصول نمايد. ازمبالغ حصول شده فوق و د ز صورت عدم تكافو به استفادهازكمك مالى دولت كه اندازه آن همه ماله دربودجه عمومى كشور ييشبينى و منظود ميشود طلبات ما كين بابت

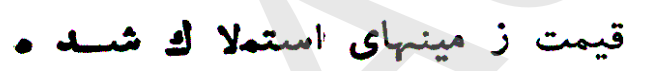
شان به اقساط ساليانه تاديه ميكرود.

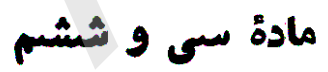

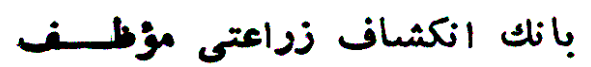
ابست در منا طقيكه بمو بب المكام

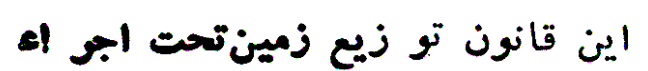

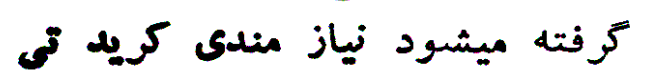
مستحقين ز مين وراتبلا تحت مطالهـ قرار داده وبراى هر منطقه هروكرام

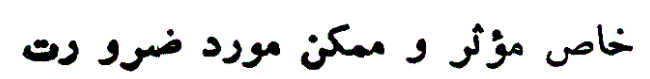
راطرح و بعد منظورى شو رايصالى خويش بمعرض اجراء قراد دمد.
ينتحَه ديرشمه ماده حويشل شو يسـو خمكــو دنبا يلو

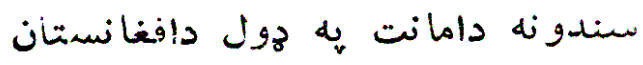

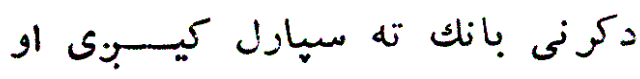

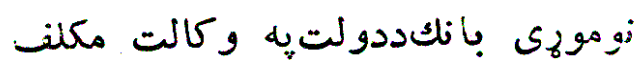

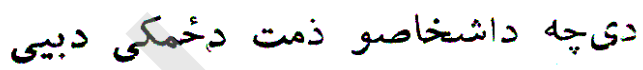

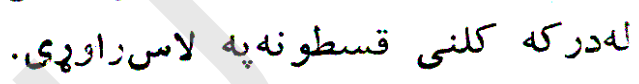

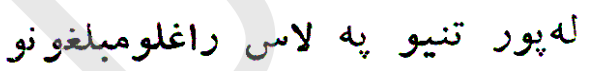

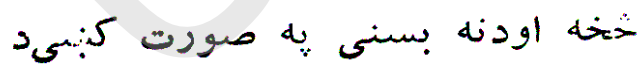

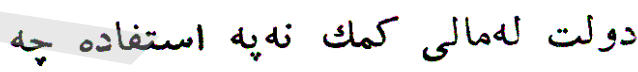

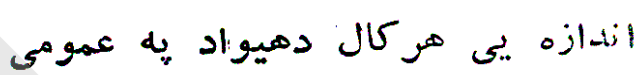

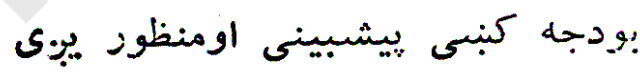

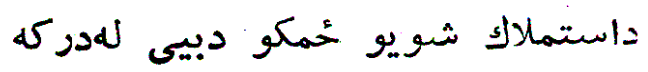

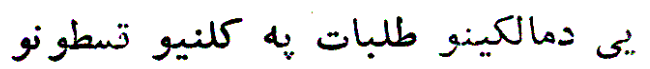
وز كول كيينى ن ثيبز ديرشمه ماده

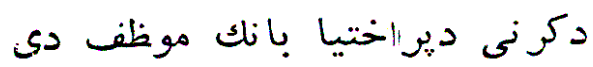

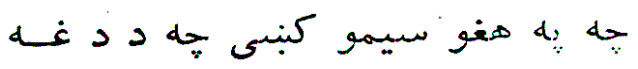

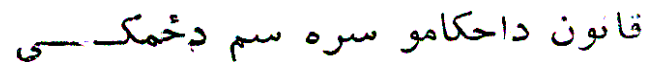

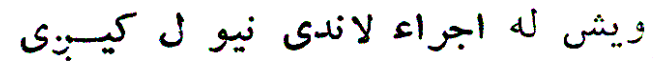

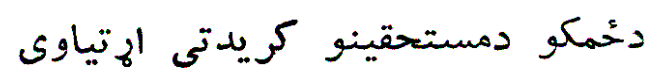
تخوا ترمطالعىلاندى ونيسى اودهيرى

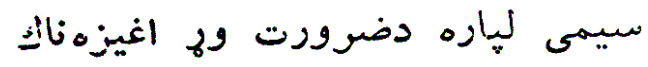

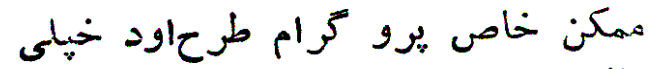

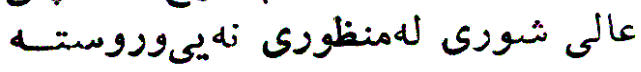
تر'اجر اه لاندى ونيسي. 


\section{थुك}

\section{فمل هفل مغنم \\ احكام متفر قهله}

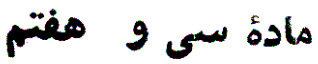

استملاك زمين هاى ما ما زاد نصاب

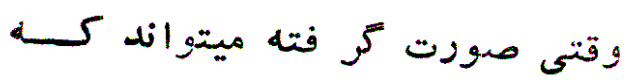

ابلاغيه رسمى قبلى شورى درساحة

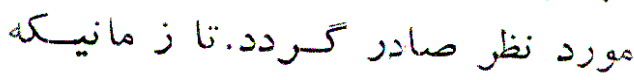

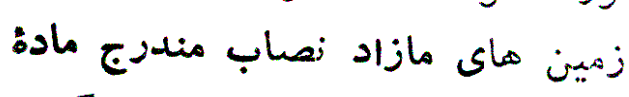

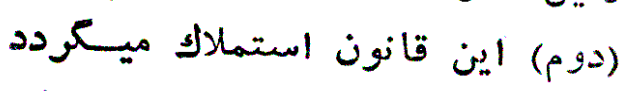

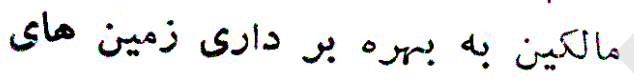

$$
\begin{aligned}
& \text { مذكوز ادامه ميد هندي بهن }
\end{aligned}
$$

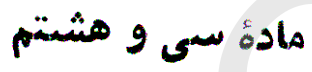

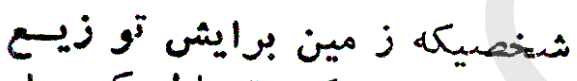

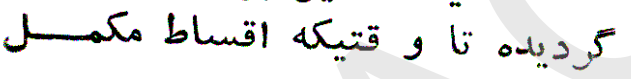

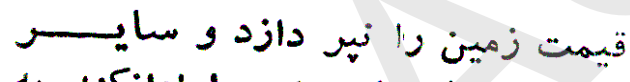

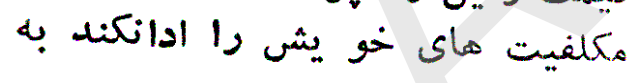

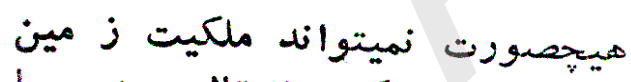

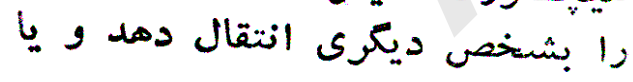

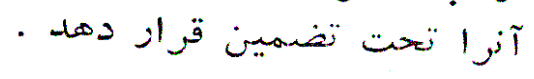

$$
\text { مادة سى ونهم }
$$

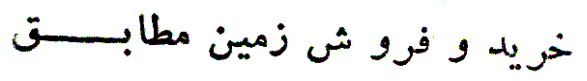

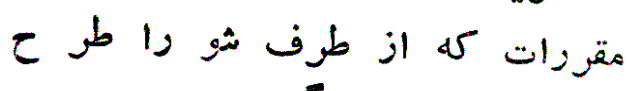

$$
\text { ميتًردد صورت مت ميكيرد. }
$$

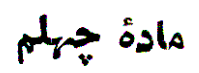

هر كاه شخصيكله زمين به اونهم اوداده شملهد سه قسط از اقساط سا ليانه ذمت خودرا بدو ن عذ و معقو لتاديه
اوم فصل

متفرقه حكمونه

اوه ديرشمه ماده

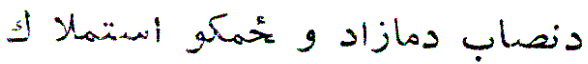

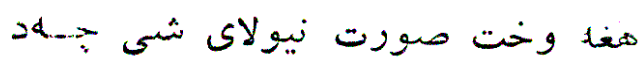

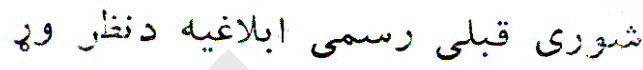

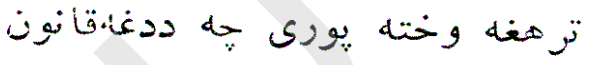

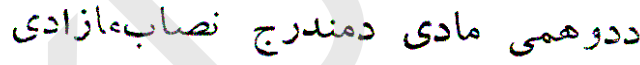

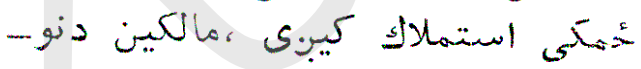

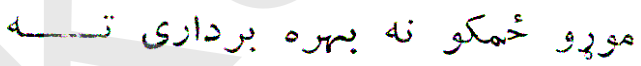

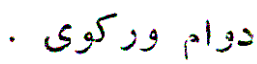
اته ديوشمه ماده

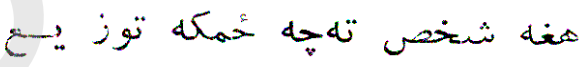

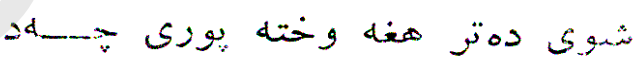

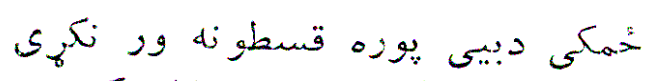

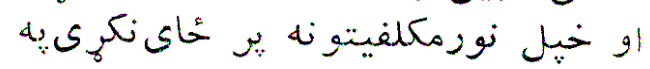

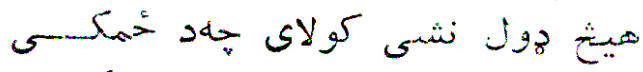

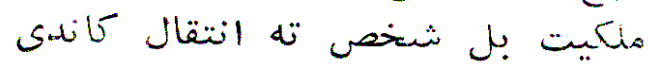

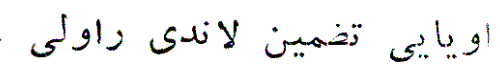

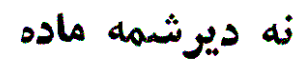

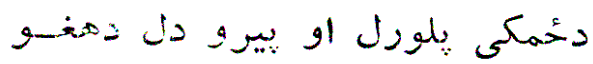

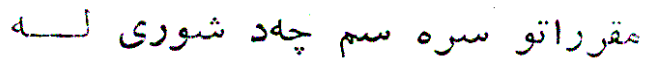

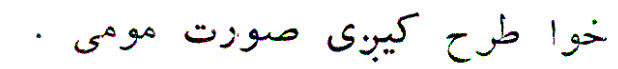
خلويبنتمه ماده

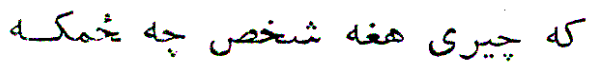

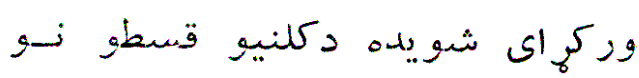

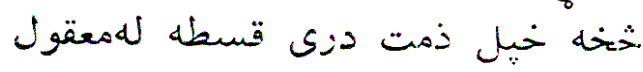




\section{?}

نكند ويا باوجود صدورابلاغيه رسمى

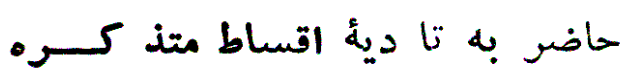

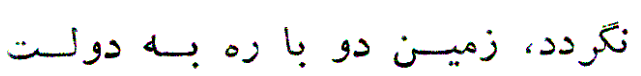

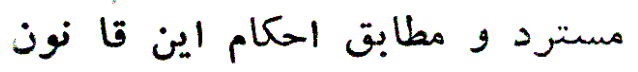
بهنشص ديكر تو زيع ميكردد.

\section{مادة جهل ويكم}

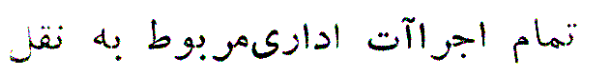

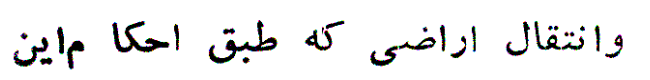

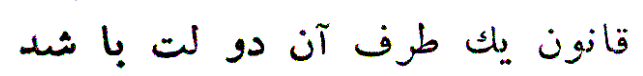

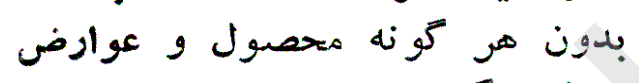
انجام ميكرد دد.

\section{مادة جهمل و دوم}

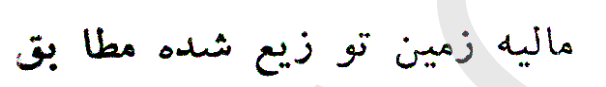

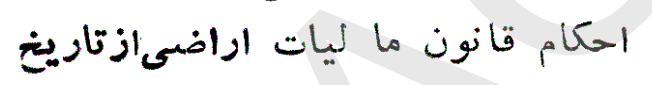

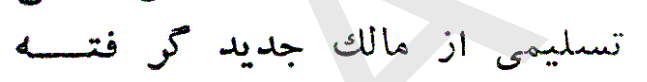

\section{مىشود - مارك \\ مادة جهل وسوم : ماد}

در صو ر تيكه شخص بدو نعنز

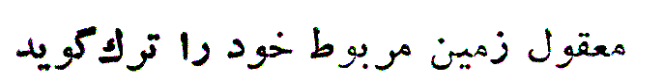
ودز طول ملت ششماه بالاى ز مين بهكثت وزراعت نير دا زد زمينش مسترد ميكردد و طبق احكام ايسـن ونس زئن

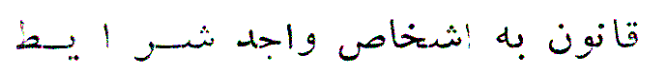
توزيع ميكردد.

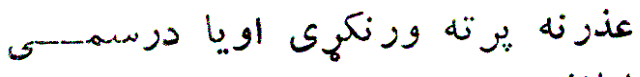

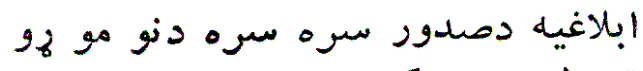

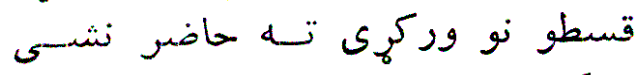

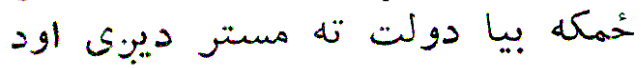

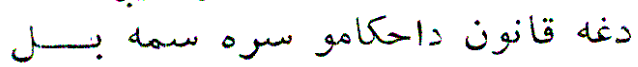

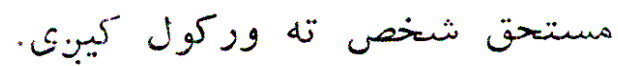
يو خلويبنتهه ماده

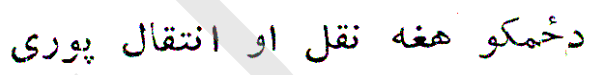

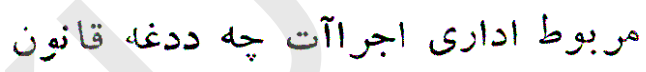

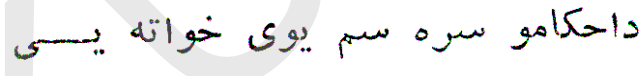

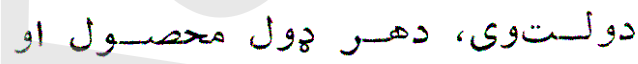

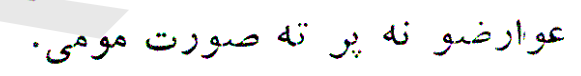
دو خلويبنتمه ماده

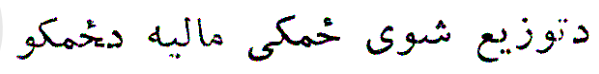

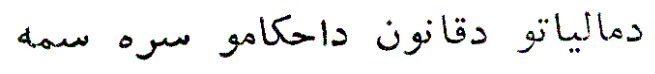

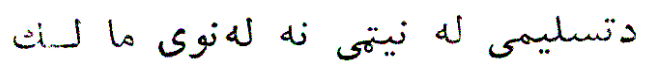

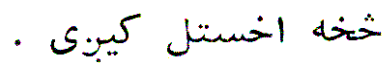
درى خلوينتتمه ماده

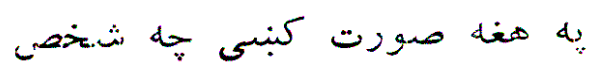

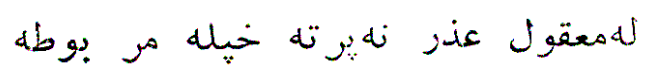

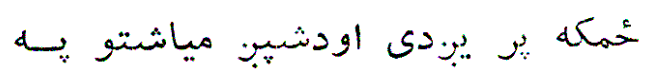

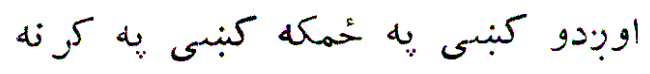

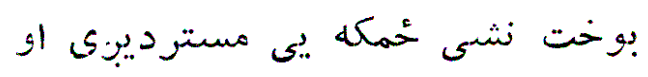

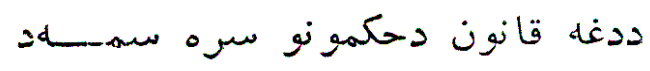

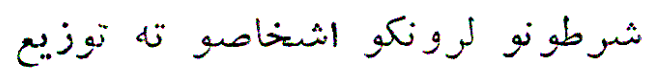
كيب.ى 


\section{?}

ماده جهل و جهارم

خلود خلويبنتهه ماده

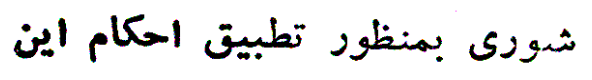

شورى ددغه قانون داحكا مـــــ

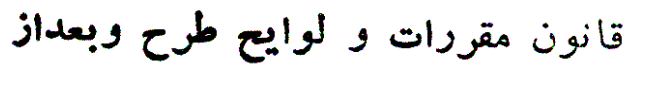

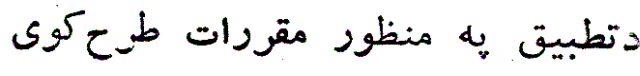

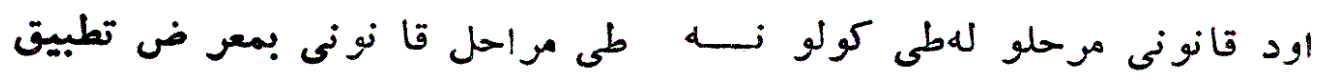

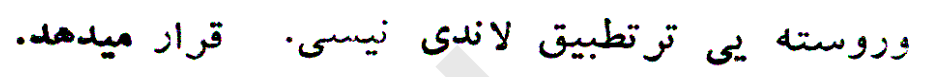

ينتخه خلوينتمه ماده

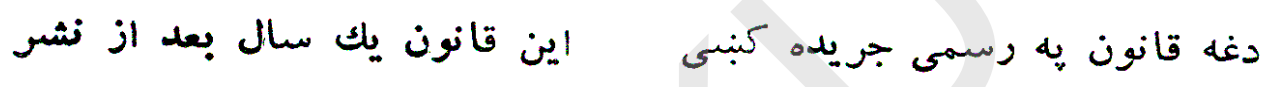

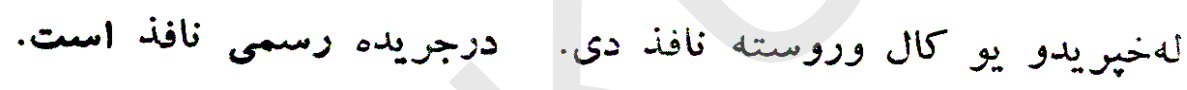




\section{ككليهونبيه}



ت تكابلكنى

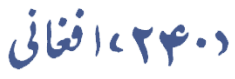

ي ولاياتّكنى

$$
\text { نيهلبيه }
$$

حيوهنى شاكرحانوت

10)|مربيكاند الره

دوى كمن بيه (•ع) الفنانى 


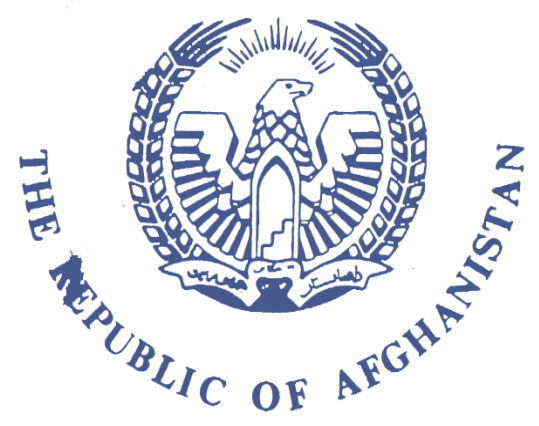

\section{OFFICIAL GAZETTE}

ADDRESS: MINISTRY OF JUSTICE KABUL, AFGHANISTAN EDITOR: M. H. TUGHYAN.

ASSISTANT EDITOR: A. HABIB AMIN

DATE: AUGUST 6, 1975

ISSUE NO. (311)

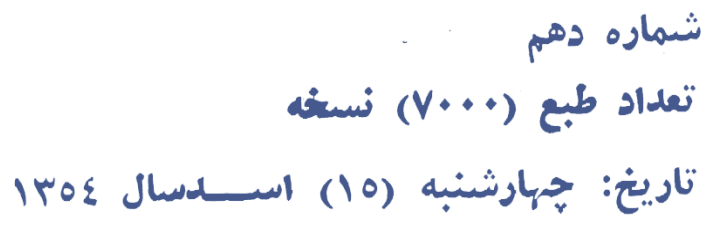

دولتى مطبعه 